\title{
Assessment of Non-Financial Criteria in the Selection of Investment Projects for Seed Capital Funding: the Contribution of Scientometrics and Patentometrics
}

\author{
Gustavo da Silva Motta', Rogério Hermida Quintella²
}

\begin{abstract}
The aim of this article is to assess the potential of using scientometric and patentometric indicators as a way of instrumentalizing the selection process of projects for seed capital funding. There is an increasing interest in technology based enterprises for their capacity to contribute to economic and social development, but there is also some difficulty in assessing non-financial criteria associated with technology for the purposes of financial funding. Thus, this research selected the case of the first enterprise invested in by the largest seed capital fund in Brazil, in order to create scientific and technological indicators and to assess the extent to which these indicators may contribute to understanding the market potential of the technology once it is assessed. It was concluded that scientometric and patentometric indicators favour the assessment process for non-financial criteria, in particular those criteria dealt with in this study: technology, market, divestment, and team.
\end{abstract}

Keywords: scientometrics; patentometrics; technological assessment; s\&t indicators; seed capital funding.

\footnotetext{
'Universidade Federal da Bahia/ Universidade Federal Fluminense, NPGA/NACIT - R. Desembargador Ellis Hermydio Figueira, 783,Aterrado, 272I3-4I5,Volta Redonda/RJ, Brasil. E-mail: gustavomotta@gmail.com

2Universidade Federal da Bahia, NPGA/NACIT - Av. Reitor Miguel Calmon S/N,Vale do Canela, 4I I I0-I00, Salvador, Brasil.

E-mail:rhquintella@gmail.com.
} 


\section{Introduction}

A detailed review of the literature on technology-based start-up enterprises shows that the study of the characteristics and behaviour of these enterprises is a relevant, main-stream subject in research in the area of innovation. This interest is expressed through the understanding that providing incentive for the emergence of start-ups is an important stimulus for regional and national economic activity (Audretsch, 1995; Reynolds, 1997; Schumpeter, 1982), for the creation of new industries (Acs \& Audretsch, 1987; Shearman \& Burrell, 1988) and for contributing to the creation of employment and revenue (Birch, 1987; Phillips \& Kirchhoff, 1989; Rickne \& Jacobsson, 1999; Storey \& Johnson, 1987; Uriona Maldonado, Dias \& Varvakis, 2009). In addition, many studies (Acs \& Audretsch, 1990, 1991; Pavitt, Robson \& Townsend, 1987; Scherer, 1965) point out that smaller enterprises tend to invest relatively more in innovation than larger ones and that, in general, productivity in research and development (R\&D) tends to be inversely proportional to the size of the business.

Interest in the subject is not restricted to academia, as can be seen from the emergence and growth of seed capital funding worldwide as well as in Brazil (Cortes, 2010; GVCEPE, 2008). This kind of funding generates a specific type of risk capital whose business model is based on obtaining long-term capital gains, increasing the value of the business and consequently selling its shares, whether to other financial groups, to strategic investors (enterprises who are interested in the business and/or products of the enterprise) or via the stock exchange by means of an Initial Public Offering (IPO) (Garcez \& Anselmo, 2005).

Just as there are various stages of development in an enterprise, there are also risk investors who focus on each one of those phases. Risk investment can basically be divided into three types:

- Angel Investor - an individual who invests in the development of innovative ideas, often before the establishment of a business;

- Venture Capital - focused on investment in emerging (Seed Capital) as well as more established businesses, both small and medium-sized, with high growth potential.

- Private Equity - investment in large enterprises, normally used for financial leverage and going public on the stock market.

The Venture Capital sector has grown in Brazil in recent years thanks to the economic climate of the country, to certain public policies, and to government actions in support of innovation. Nonetheless, one cannot ignore the fact that investment funds seek capital gain and that they invest in start-ups because they recognize the potential these businesses have in that respect.
The Seed Capital Fund chosen for this study is the biggest in Brazil (Cortes, 2010). It was established from an initiative of the Banco Nacional do Desenvolvimento Econômico e Social (BNDES) and came into being in November 2007, with a value of $R \$ 100$ million and shares subscribed by BNDESpar and by the Banco do Nordeste do Brasil (BNB) (CGEE, 2008).

In Brazil, only I\% of projects submitted to risk investors make it through to the end of the process and receive investment (Carvalho, Ribeiro and Furtado, 2006). In this process of identifying and selecting opportunities, the investors analyze business plans with the intention of choosing the most promising ventures and they therefore adopt varied selection criteria (Ferreira, 2007; Souza, 2008). The Seed Capital Fund selected for this study uses five assessment criteria: Team, Technology, Market, Need for Capital and Divestment.

These criteria are classified, in this study, according to their nature, as financial and non-financial. Exclusively financial criteria, such as Need for Capital, may be contrasted with exclusively non-financial criteria, such as assessment of Team and Technology. There are also mixed criteria, such as assessment of Market and Divestment, which combine both financial (market size, volume of transactions, availability of investment resources in the area, etc.) and non-financial aspects (qualitative market evolution and strategic interests of players in the area).

The financial criteria use economic assessment instruments that are universally accepted for the assessment process, such as risk analysis, break-even analysis, cost structure, return on capital investment, etc. The non-financial criteria, due to their nature, call for the need to objectify a process which is naturally subjective.

For example, if we look at the assessment process for project investment in general, the risk managers usually analyze the track record (history, experience, training, and achievements) of the project team, mainly taking into consideration the level of training and entrepreneurial capacity. With respect to technology, in general, the scientific basis and possible competitive advantage of the technology are analyzed. With reference to the non-financial aspect of the market, normally the capacity of the technology to solve a problem that is clearly present in the market is assessed, that is, it is necessary to verify whether there is in fact a demand for the technological solution in question. Finally, in relation to the non-financial criteria of divestment, in general, the existence of strategic partners with potential interest in the technology is considered.

Despite their apparent logic, the non-financial criteria are challenged with making the assessment of subjective aspects

ISSN: 07 I8-2724. (http://www.jotmi.org)

Journal of Technology Management \& Innovation @ Universidad Alberto Hurtado, Facultad de Economía y Negocios. 
objective, leaving the attribution of points for the assessment of projects at the mercy of the personal judgement of a director. It is from this context, which contrasts the importance - both at a business level as well as at a wider social level - of investment in start-ups, with the difficulty of assessing those with greater potential to receive seed capital investment, that the main objective of this research arises: The assessment of the potential of using scientometric and patentometric indicators as a way of instrumentalizing the selection process of projects for seed capital funding. For this purpose, public data relating to the first enterprise invested in by the Seed Capital Fund chosen for this assessment will be used in this study.

This article is presented in five parts, in addition to this introduction. The first part consists of a bibliographical review which focuses on the definition of scientometrics and patentometrics and on bringing together the principal scientific and technological indicators used in order to better understand the dynamics of Science and Technology (S\&T). Then the research methodology is presented, followed by the data collected during the research and, finally, the data is analyzed and the conclusions and limitations of the study are presented.

\section{Scientometrics and Patentometrics}

Scientometrics is a discipline which offers methods, based on bibliometrics, for the study of Science, Technology and Innovation (STI) (Callon, Courtial \& Penan, 1995). According to Gregolin (2005), scientometry, or the science of sciences, encompasses the study of physical, natural and social sciences, with an aim to understanding their structure, evolution and connections so that relationships between science and technological, economic and social development may be established.

Some authors (Jannuzzi, Gomes and Andrade, 2003; Maricato, 2010; Velho, 1997) consider that scientometric and patentometric assessment by researchers, institutions and countries is already commonplace among the most diverse of social actors. Aspects like productivity, quality of research, and collaboration and cooperation in STI are taken into consideration when making political decisions on Science and Technology systems (Velho, 1997), when making business decisions relating to R\&D management (Jannuzzi, Gomes and Andrade, 2003) and when researchers are making academic decisions (Maricato, 2010).

Although Patentometrics is a technique which is part of the group of analytical methods belonging to bibliometrics, it is, nonetheless, distinguished from these methods in that it is the metric study of the characteristics and uses of patent documents (Guzmán Sánchez, 1999), considering the impor- tance of patents as an instrument of technological innovation and to assess the relevance of technology (Carvalho; Oliveira; Winter \& Mothe, 2009; Carvalho; Winter; Mothe \& Carestiato, 201 I). Moreover, Okubo (1997, p.9) considers Bibliometrics to be multidisciplinary and applicable to a wide variety of different fields. In general, the different applications are mainly utilized for the measurement of documented information contained in information and communication systems.

Various authors (Bufrem \& Prates, 2005; Hood \& Wilson, 2001; Macias-Chapula, 1998; Sengupta, 1992; Spinak, 1998) agree that the terms Bibliometrics, Scientometrics and Patentometrics, among others, follow the same logic which denotes "metric studies" applied to different media (books, science, patents, information, Internet, etc.). In this way, they basically all make use of the same quantitative techniques.

In general, a bibliographical review can easily indicate that, of the collection of methods and techniques covered by metric studies of information, bibliometrics is central and integral and may be considered as a "parent discipline", showing interdisciplinary correlation with the others, and at the same time, possesses its own particularities and applications.

For the construction of scientometric and patentometric indicators, the most common media for publishing scientific and technological information were used.These were scientific articles and patents, respectively. The decision to work with articles and patents is related to the specific nature of these elements in the construction of indicators. For Spinak (1998), there are two distinct categories in the analysis and representation of information which constitute the basis for scientific indicators: input and output. Articles and patents are classified as output, since they represent the product of the S\&T development process.

Spinak (1998) points out that input indicators are less complex than output ones. For Maricato (2010), scientific and technological indicators were originally almost completely limited to the analysis of input, which was somewhat generic, such as the percentage of GDP per capita destined to S\&T activities. With these limitations, decision makers and strategists employed in the area of S\&T and R\&D gradually became interested in output indicators. Some of the principal input and output indicators for scientific and technological activities are presented in Figure I below (Guzmán Sánchez, 1999). 

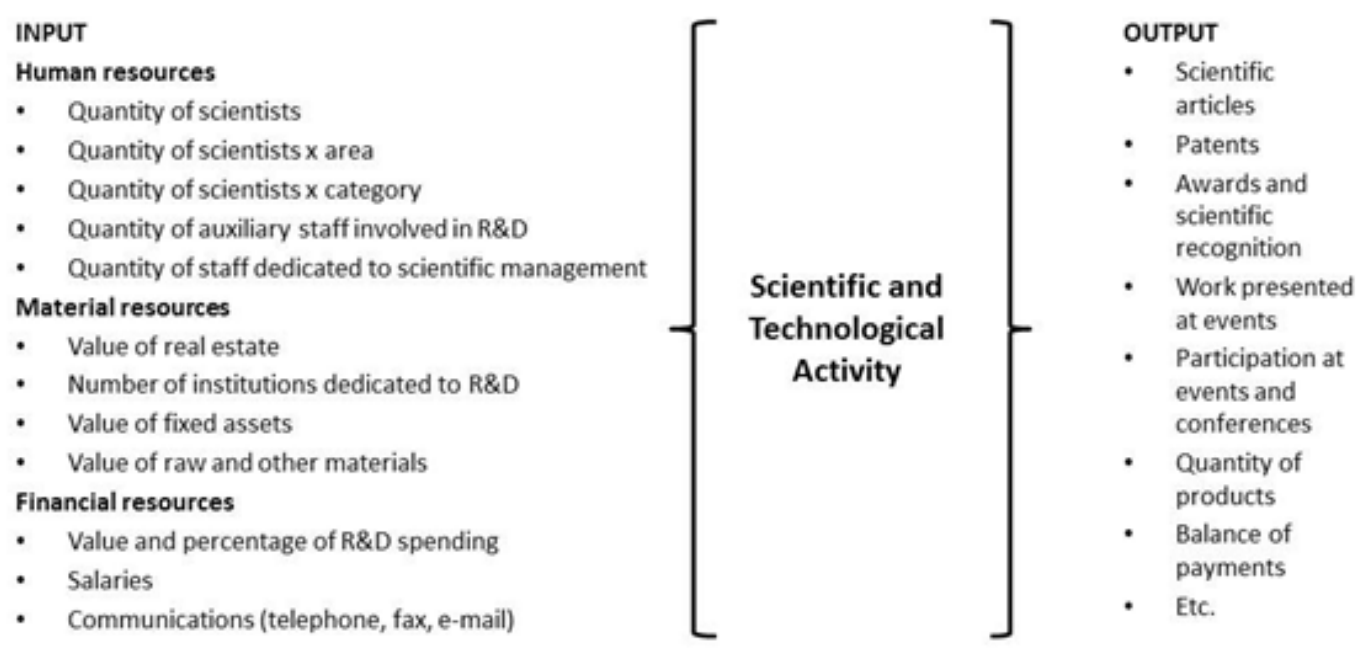

Figure I. Input and output of scientific and technological activity. Data based on Guzmán Sánchez (1999).

Maricato (2010) divides the bibliometric indicators into three categories:

I. Indicators aimed at measuring scientific and technological productivity, the principal indicators being the number of scientific publications and registered patents;

2. Indicators aimed at making estimations with regard to the use and quality of published documents, mainly based on the study of citations;

3. Indicators of collaboration aimed at analysing, above all, collaborative social networks established among researchers, institutions, countries, etc.

The indicators of collaboration mainly use analysis techniques of co-authorship in the case of articles, and of coinvention and co-ownership in the case of patents. Based on these indicators, various types of lists, graphs, tables, maps, etc. can be created which are applicable to the study of the most diverse of scientific and technological fields.
The principal metric indicators, according to Macias-Chapula (1998, p. 137), are presented in Figure 2.

Spinak (1998), in a seminal work, presents his vision on the information most relevant to scientometrics:

- The quantitative growth of science;

- The development of the fields and sub-fields of knowledge;

- $\quad$ The relationship between science and technology;

- $\quad$ Obsolescence of scientific paradigms;

- Communication networks among scientists;

- $\quad$ Production and creativity of researchers;

- Relationships between scientific development and economic growth;

- Others.

In addition, Spinak (1998, p. I43) considers that scientometric techniques may have the following principal applications, among others:

Number of studies - reflects the products of Science, measured by counting the studies and by the type of document (books, articles, scientific publications, reports, etc.). The research dynamic in a particular country may be monitored and its trends charted over time.

Number of citations - reflects the impact of the articles or topics cited.

Co-authorship - reflects the degree of collaboration in science at national and international level. The growth or decline in cooperative research may be measured.

Number of patents - reflects the trends in technical changes over time and assesses the outcomes of resources invested in R\&D.

These indicators determine the approximate degree of technological innovation in a country.

Number of citations of patents - measures the impact of the technology.

Maps of scientific fields and of countries - assist in detecting the relative ranking of different countries in relation to global scientific cooperation.

Figure 2. Principal Metric Indicators. Data from Macias-Chapula (1998, p. I37)

ISSN: 07 I8-2724. (http://www.jotmi.org)

Journal of Technology Management \& Innovation (c) Universidad Alberto Hurtado, Facultad de Economía y Negocios. 
- Identifying trends and increasing knowledge in different areas;

- Investigating scientific journal coverage from one nucleus and from secondary sources;

- Identifying actors from the different areas;

- $\quad$ Studying the usefulness of services for the selective spreading of information;

- $\quad$ Predicting trends in publication;

- $\quad$ Studying the dispersion and obsolescence of scientific literature;

- $\quad$ Assisting in the processes of indexation, classification and automatic generation of abstracts;

- Analyzing the productivity of editors, individual authors, organizations and countries.

In this research, it is understood that these applications, used in analyzing the dynamics of scientific production, may also be used in the analysis of technological production when referring to patents rather than articles. It is thus seen that, when attempting to understand the relationships and dynamics involved in Science and Technology, the scientometric and patentometric indicators become opportune. According to Maricato (2010), there are various indicators used in the analysis of this relationship. Notable, among others, are the number of articles cited, citations of patents in scientific articles, publication of scientific articles by inventors, registration of patents by researchers, etc.

With respect to this interactive process between Science and Technology, Campos (2006) concludes that there is:

[...]contribution of academic knowledge to technological development through the citing of scientific articles in patent texts. What's more, the contribution of private R\&D for scientific progress is apparent in the analysis of joint publications between people in industry and those in universities and public research institutes. Here, the analyses are based on counting texts whose authors include researchers linked to academia as well as to industry, or which may represent the authors' contribution to academic knowledge. This therefore leads to a double contribution to the innovation process, which occurs both in academic research for private technological development as well as in private R\&D for scientific development codified in publications. This dynamic, since it is illustrated by empirical data on patents and publications, reinforces the theoretical validity of the interactive model.

Thus, it may be concluded that the interactive process between Science and Technology may be investigated based on scientometric and patentometric evidence, since they frequently permit the analysis of mutual contributions between science and technology.

\section{Methodological Strategy}

For the purposes of this study, data was used from articles and patents related to the technology of an enterprise invested in by the Fund chosen for this analysis. The enterprise carries out research in the area of phytopathology focusing on the biological control of blight. Its principal process is aimed at producing and applying Pochonia Chlamydosporia , a fungus which develops on the surface of plant roots and colonizes nematode egg mass (a blight which affects various different types of crop) and eliminates them. The technology investigated is therefore considered to be: the application of the Pochonia Chlamydosporia fungus as a nematicide for various crops.

Once the technology to be studied was classified, a definition of the search topic to be used for the extraction of related articles and patents was chosen, according to the outline of the methodological procedures of the present study, which is presented in the Figure 3 below, and will be explained in detail and discussed throughout this section. The data collected, in accordance with the search topic chosen, defined what will be referred to throughout the process of analysis in this article, as the "Area".

The topic was composed of the terms "pochonia chlamydosporia" - the name of the fungus produced by the Enterprise - "verticillium chlamydosporium" - its former denomination - and "nematicide" - its function. In this way, it is possible to identify articles and patents related to the fungus and to its application as a nematicide. Thus, the search looks at the fungus in its application as a nematicide, as well as other applications, important in terms of derivation of new products. The search also looks at alternative forms of controlling nematodes, which is particularly important for the verification of competitor's products, such as synthetic nematicides, for example. The Web of Science (WoS) was selected as the data source for the extraction of articles, and the Derwent Innovation Index (DII) was chosen for the extraction of patents. These databases were chosen since they both belong to Thomson Reuters, thus facilitating the systemization of data relating to different documents (articles and patents) and because they are the databases with the greatest volume of data that are available free of charge at the Brazilian Public Universities through the CAPES post-graduate research agency. This search was carried out on the 2 lst of December $201 \mathrm{I}$ and was validated by the principal entrepreneur of the Enterprise analyzed in this study.

Translation of the original: (Campos, 2006, p. I60).

Previously named Verticillium Chlamydosporium

ISSN: 07I 8-2724. (http://www.jotmi.org)

Journal of Technology Management \& Innovation (c) Universidad Alberto Hurtado, Facultad de Economía y Negocios. 


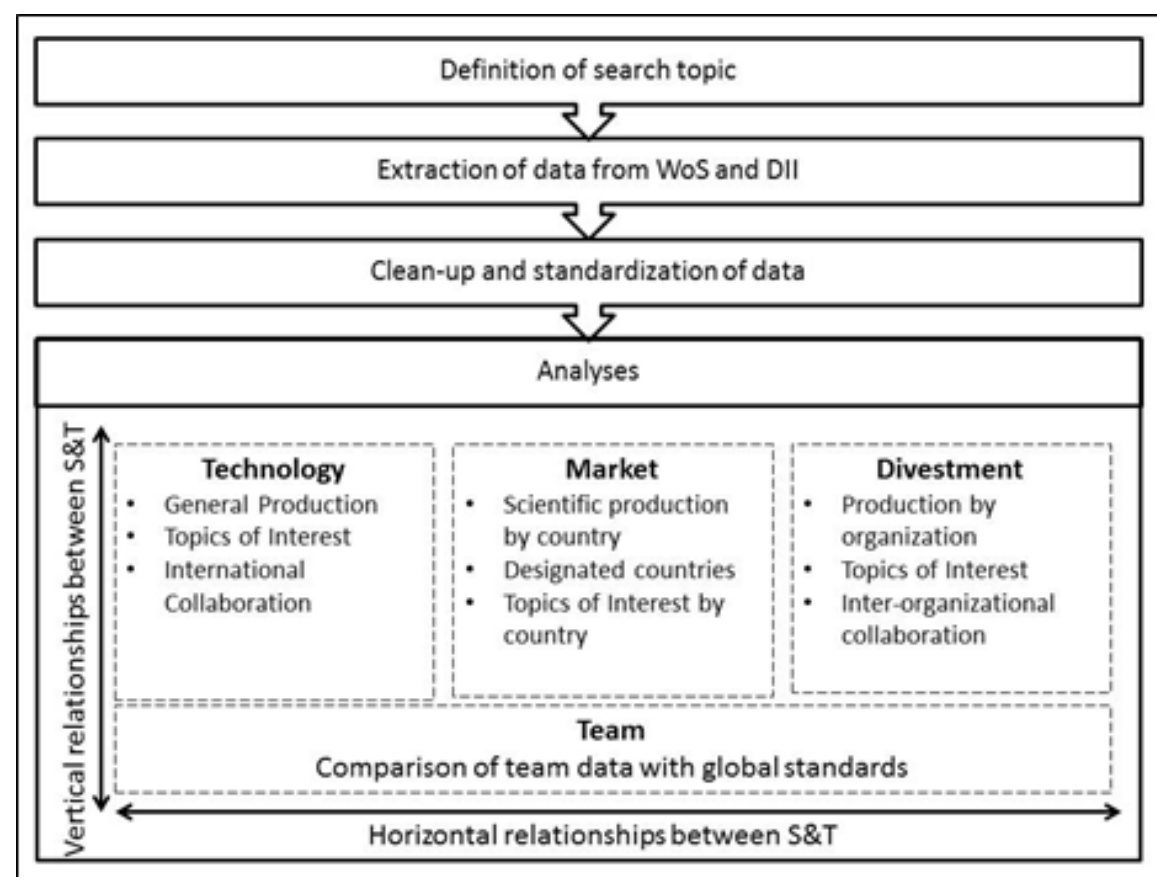

Figure 3. Outline of Methodology

Before the analyses, it was necessary to clean up and systematize the data extracted, with an aim to eliminate inconsistent or redundant data. This step was carried out with the help of VantagePoint v.7 software. The data analyzed from the patents and articles extracted in accordance with this study's methods were: Organizations, Countries, Data and Topics of Interest. Thus, within the Area, represented by the collection of data from scientific and technological production related to the technology analyzed, there are more specific topics, referred to here as Topics of Interest.

The "Organizations" were identified, in the articles, using the Author Affiliations field, and for patents, using the Patent Assignee field. In cases where more than one organization or country was associated with a document, a record was made for each one.

The "Countries" identifier was made, for the articles, using the Country field and for the patents, using the Designated States National field. In this way, the country where the author's affiliated organization is located (and not the author's nationality) is taken into consideration in the case of articles, as well as the country or countries where the patent was protected. With this last piece of information, in accordance with the assumed premise of this study, it is possible to identify countries (markets) of interest for the protection of the technology. In cases like that of the United Kingdom, for example, in which patents from all four countries (Northern Ireland,Wales, England and Scotland) are classified under the denomination, UK, articles were also classified in a similar manner, that is, for all four countries.

The "Date" considered for analyses, graphic representation of data, creation of tables, and respective analyses of organizations and countries, was the year of application in the case of patents, and the publication year in the case of articles.

For the classification of "Topics of Interest", the International Patent Classification (IPC) was used. As there is no international classification for articles, it was decided, along the same lines as the IPC, to use the WoS's Subject Category field*. For the joint analyses of topics of interest between patent documents and articles, it was necessary to integrate and adapt the classifications. Taking into account the aim of this study, it was decided to focus on the technological classification. The IPC considers eight principal sections (Human Necessities; Performing Operations; Transporting; Chemistry and Metallurgy; Textiles and Paper; Fixed Constructions; Mechanical Engineering / Lighting / Heating; Physics; and Electricity) and close to 70,000 subdivisions (Armond-deMelo, 2012).

*This field is classified by the WoS itself at the time of indexing a journal, taking into consideration the following criteria: (a) thematic scope and focus of the journal; (b) author affiliation and editorial council; (c) financing agencies who provide resources; (d) cited references; (e) official sponsor of the journal; ( $f$ ) classification in other databases. In this way, Thomson Reuters was attributed up to six different categories for the same journal.

ISSN: 07 I8-2724. (http://www.jotmi.org)

Journal of Technology Management \& Innovation (c) Universidad Alberto Hurtado, Facultad de Economía y Negocios. 
For this analysis, data was grouped according to the technological fields proposed by the WIPO (World Intellectual Property Organization) IPC and Technology Concordance Table. Thus, the analysis is not limited to the IPC's eight sections (which could lead to an inadequate grouping of technologies with few connections between them), nor are all seventy thousand subdivisions considered (which would make the analysis unviable). For the classification of articles, then, the procedure used here took the following steps: (I) identification of the topic of interest category; (2) standardization of the Topics of Interest according to the technological field, with an aim to accomplishing previous approximations between scientific production and technology in the area.

The analysis of the dynamics of networks of scientific and technological collaboration was performed using techniques of occurrence and co-occurrence of countries and organizations (authors' affiliation to organizations in the case of articles, and rights holder organizations in the case of patents). For this stage of the research, the software UCINet v. 6 and NETDRAW v. 2 was used, just as done by Quintella et al. (20I2).

In this way, the scientific articles and patent documents were analyzed by country and by organization and its subcategories (Academies, Enterprises and Government), taking into consideration the following characteristics:

- Scientific and technological production (quantity of articles and patents produced);

- Topics of interest identified in the articles and patents;

- Activities of scientific collaboration and technological collaboration.

This data was considered due to the non-financial elements analyzed during the selection process of proposals for the seed capital Fund studied here. Thus, characteristics of general production, of topics of interest, and of scientific collaboration, provided information for the assessment of Technology (I); data on countries was used for the analysis of Market (2); organizational production, such as inter-organizational collaboration and patent registration, were used for

UCINET is one of the principal programmes used in Social Network Analysis for calculating the principal indicators, such as network density and centrality of nodes, among others. NETDRAW is a graphic programme which permits the visualization, in the form of graphs, of actors in a network, the connections between them, and their characteristics.

VantagePoint is a programme containing tools for text mining and correlation of significant clusters of structured textual data, such as databases. the assessment of withdrawal of funding from shares in the enterprise, or Divestment (3). For the assessment of Team (4), a comparative analysis was carried out of the general data related to the enterprise's technology, general production, topics of interest, and collaboration of team members, on the global stage. VantagePoint software was used for crossing variables, and for the creation of tables and graphs along with their respective analysis and statistical calculation.

\section{Presentation of data}

In keeping with the proposal, the data are analyzed in this section in four dimensions, which correspond to the nonfinancial criteria adopted by the organization being studied: Technology, Market, Divestment and Team. For each of these dimensions, there is an array of indicators which will be constructed with an aim to assess the technology and the enterprises from the perspective of the Fund.

\section{I Technology}

For the assessment of technology associated with the enterprise's product, data relative to the general productivity of articles and patents was searched for, as well as topics of interest and the dynamics of international collaboration in the production of articles.

The analysis of the volume of article publication and its evaluation over time constitutes the most basic stage in the process of analysis. Despite its simple nature, this indicator will subsidize all the other more specific indicators and analyses. The Scientific Production identified based on these search terms consisted of $82 \mathrm{I}$ articles, from 1945 on (WoS time bracket). The technological production related to the Pochonia Chlamydosporia fungus as a nematicide in the Dewent Innovation Index (DII) database presented 258 patents, whose registration corresponded to the period between 1979 and 20II. The annual evolution of articles and patents is represented in the Figure 4 below.

An increase in production related to the application of Pochonia Chlamydosporia fungus as a nematicide can be seen in both scientific and technological terms (see Figure 4), with the first article being published in 1954 and the first patent in 1975. Taking the evolution of article publication as a base, seven different phases may be observed (highlighted in the Figure 4), of which the last three represent a more significant volume of production, as well as more regular patterns. As the year was not finished at the time of data extraction, $201 \mathrm{I}$ was excluded. For this reason, the period considered for the purposes of this study will be 1991 to 2010 .

The publication of patents follows a different dynamic to the publication of scientific articles, as well as having specific

ISSN: 07 I8-2724. (http://www.jotmi.org)

Journal of Technology Management \& Innovation (c) Universidad Alberto Hurtado, Facultad de Economía y Negocios. 


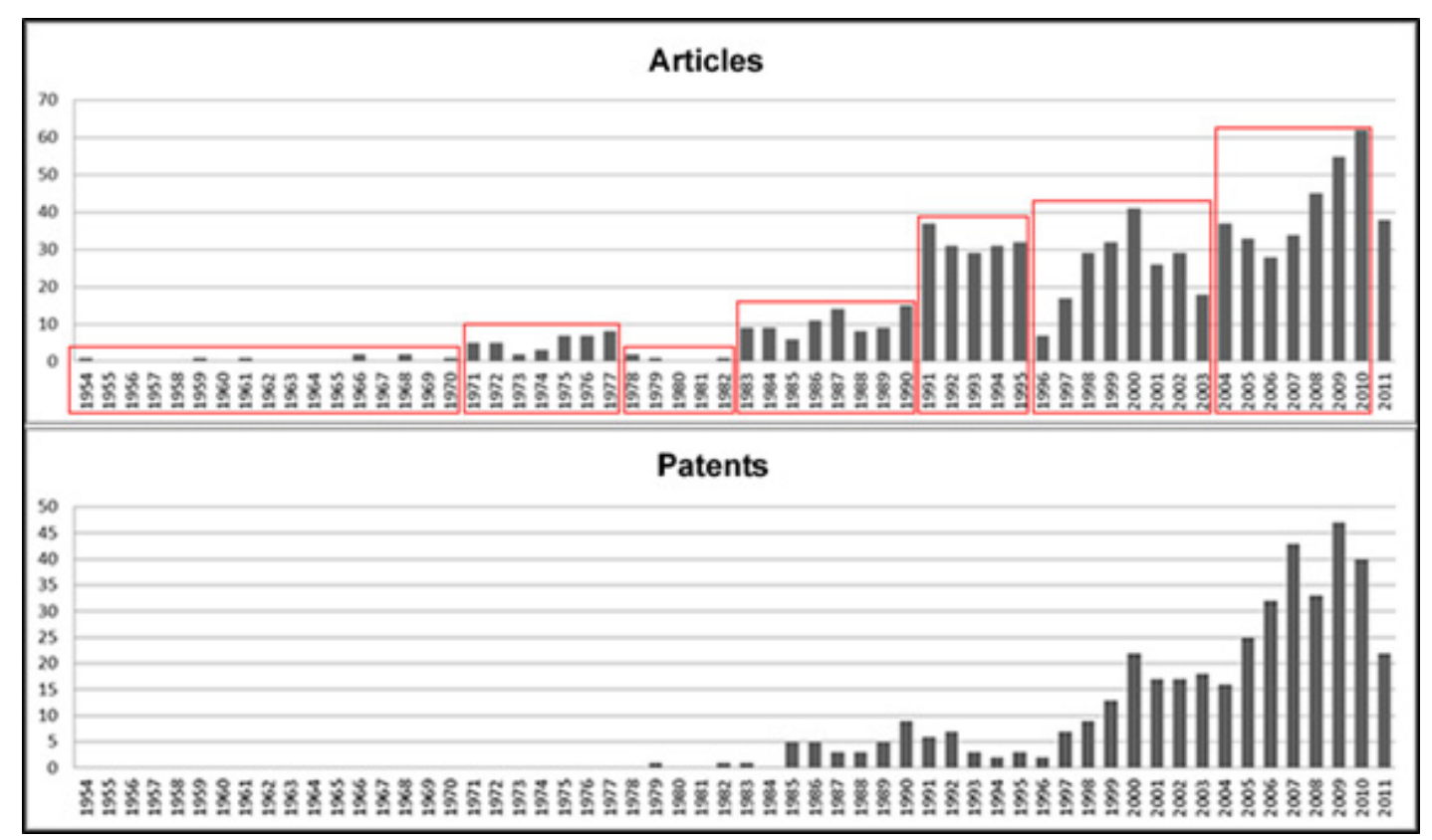

Figure 4. Evolution of the global production of articles and patents related to the application of Pochonia Chlamydosporia fungus as a nematicide

publishing procedures according to country, as pointed out by Martin et al. (2002). According to the authors, in the majority of countries, patents are published 18 months after their date of priority, which is the date of deposit of the patent in the first country where it is deposited (Country of Origin).This period of secrecy is independent of whether the patent is granted, rejected, or still pending a decision. Therefore, it is likely that the data on patents for the last two years (in this case only 2010, since the DIl search was carried out in December 20II) are incomplete.

It can also be seen that the values for priority year and deposit year decline after 2009. As previously explained, this fact is a result of the period of secrecy, normally lasting 18 months, in which patents remain secret before their publication. In this way, there is always a delay between the deposit and priority data and their respective publication, as underlined by Oldham (2007). Therefore, the Basic Patent Year field, on the one hand, shows a delay with respect to

The Paris Convention is an international treaty relating to Intellectual Property, signed by 14 countries (including Brazil) in Paris in 1883. There are currently 173 signatory countries. Its objective is the compulsory observance by signatory countries of certain fundamental principles. The principle of Union priority states that the first application for a patent, filed in one of the treaty countries, serves as a base for subsequent applications related to the same subject and made by the same applicant, or his or her legal successors, within a period of 12 months.

From Portuguese: Indicador de Aproveitamento de Oportunidades. technological production. On the other hand, the Priority Year field may be earlier than the patent application, in the event that this is related to the principle of Union priority in the Paris Convention. Thus, it was decided to use the data from the Application Year field for the analysis of technological production.

Once the time bracket was established, the total volume of scientific production on the application of Pochonia Chlamydosporia fungus as a nematicide was reduced from 821 to 653 articles ( $80 \%$ of the total number) and the volume of technological production reduced from 258 to 226 patents ( $88 \%$ of the total). Based on this information, it is possible to create an indicator equivalent to the IAO (Utilization of Opportunities Indicator) (Albuquerque, 1997, 1998; Albuquerque and Sicsú, 2000) for the area. Originally, the IAO was created to assess the National Innovation Systems (NIS). According to Albuquerque and Sicsú (2000), given the complexity of the relationship between science and technology, a comparison between the two relative values offers clues to the quality of interactions between them. The greater this indicator, the more mature the NIS, that is, the lesser the distance between the quantities of scientific and technological production. In immature systems, scientific production is greater than industrial-technological production, implied in a low IAO, which leads to the diagnosis of the existence of waste of opportunity.

Similarly, it was sought to assess the relationship between the volume of scientific production and of technological

ISSN: 07 I8-2724. (http://www.jotmi.org)

Journal of Technology Management \& Innovation (c) Universidad Alberto Hurtado, Facultad de Economía y Negocios. 


\begin{tabular}{|l|l|l|}
\hline Topics of Interest Categories & Articles & Patents \\
\hline Agriculture & 278 & 200 \\
\hline Veterinary Science & 251 & 43 \\
\hline Biotechnology & 54 & 0 \\
\hline Biochemistry & 52 & 41 \\
\hline Others & 46 & 12 \\
\hline Chemistry & 39 & 68 \\
\hline Ecology & 36 & 0 \\
\hline Mycology & 36 & 0 \\
\hline Measurement & 0 & 11 \\
\hline Fertilizers & 0 & 10 \\
\hline Pulverization & 0 & 5 \\
\hline Various materials & 0 & 4 \\
\hline Chemical/Physical Processes & 0 & 3 \\
\hline Computing & 0 & 2 \\
\hline Containers & 0 & 2 \\
\hline
\end{tabular}

Table I.Topics of interest of articles and patents related to the application of Pochonia Chlamydosporia fungus as a nematicide.

production in the area studied, with an aim to identifying the maturity of this area in relation to utilization of opportunities. Thus, between 1991 and 2010, the approximate relationship was 0.346 patents per article, which would classify the area, according to Albuquerque (1998) on the threshold between mature and immature systems, since this indicator is very close to the average, which was calculated as 0.386 . Meanwhile, when verifying the average annual growth rate, which is $23 \%$ for patents and $14 \%$ for articles, a tendency towards a more technological focus in the area is noted. Therefore, it may be considered that this technology is in a phase of growth and that the utilization of opportunities is moderate, with a tendency to increase.

The average annual number of scientific articles published between 1991 and 2010 was 32.6.Analyzing the volume from 2002 (29) and 2008 (45), an increase of 55\% was verified, greater than the average global increase in scientific publications in general, which was $34.5 \%$, for the same period according to UNESCO (2010). In addition, when comparing the average for 199I to 2007 ( 28.8 articles) with the average for 2008 to 2010 (54 articles per year), an intensification can be seen in these last three years. Therefore, it can be verified that recent production has been ever increasing in both absolute and relative numbers and shows a tendency towards growth in the coming years, showing, in fact, increased scientific interest awakened by this technology.

In relation to technological production, 18.1 patents were deposited in the period between 1991 and 2010. When comparing the total number of patents registered in 1991 with those registered in 2009 (peak of annual production for the period), an increase of $683 \%$ can be seen. This data shows a significant increase in technological production in the area, demonstrating its more technological focus during this period.

The articles and patents related to the application of Pochonia Chlamydosporia fungus as a nematicide were grouped into ten topics of interest, as seen in the Table I.

The evolution of the four principal topics of interest in the articles is represented in the Table I.A much greater share of articles may be noted under the topics of Agriculture $(43 \%)$ and Veterinary Science (38\%), followed by Biotechnology and Biochemistry, with approximately $8 \%$ each. Of these four principal topics, the Figure 5 shows that Agriculture and Biochemistry show a more intense growth trend, that Veterinary Science is stagnant at a high volume of production, with a certain amount of recent growth, and that Biotechnology shows a peak in 2008, but decreased in recent years. Thus, it is the topics of Agriculture and Veterinary Science that attracted most interest in global terms.

The distribution of annual evolution of patents deposited in the period between $199 \mathrm{I}$ and 2010 related to the technology in question is described in the Figure 6. It may be observed that approximately $88 \%$ of these patents are classified under the topic of "Agriculture". 

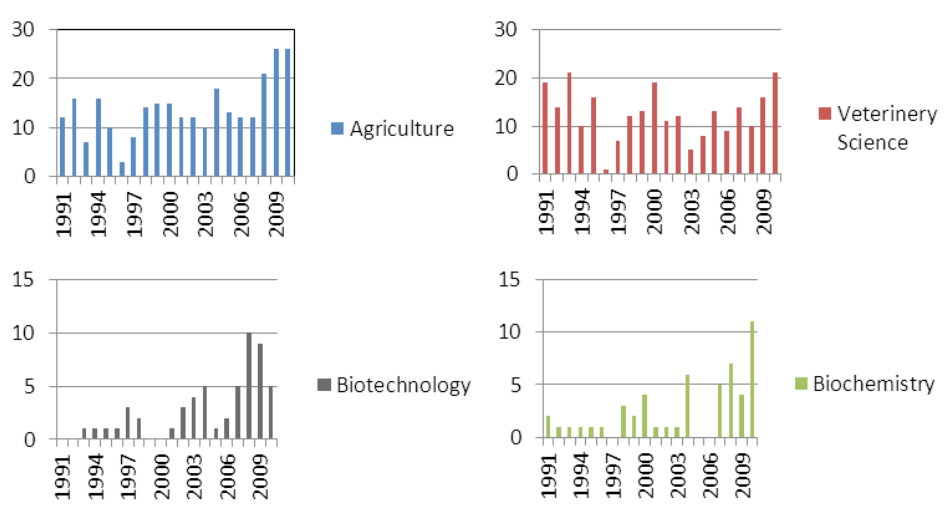

Figure 5. Evolution of the four principal topics of interest in articles related to the application of Pochonia Chlamydosporia fungus as a nematicide

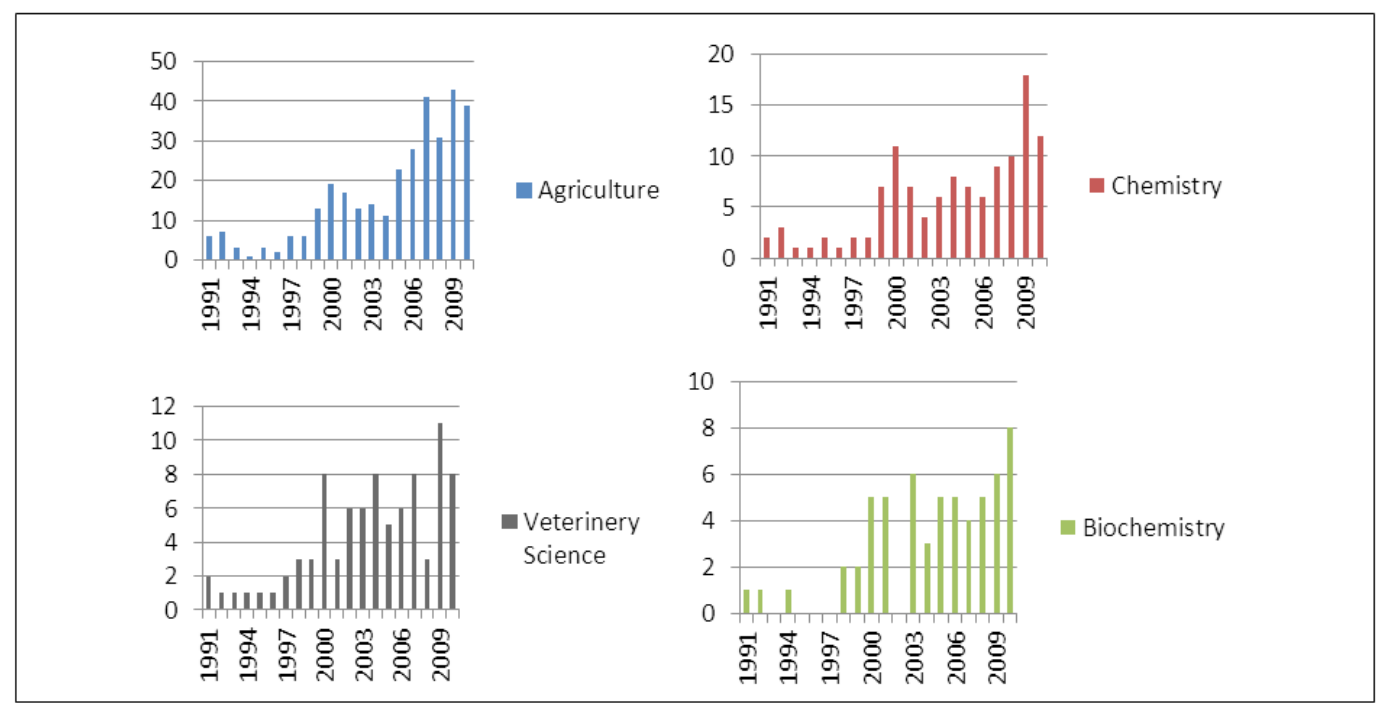

Figure 6. Evolution of the four principal topics of interest in patents related to the application of Pochonia Chlamydosporia fungus as a nematicide

It can be seen from the Figure 6 that the four principal topics of interest (Agriculture, Chemistry, Veterinary Science and Biochemistry) show a growth tendency and a significant increase in volume in the last ten years of the period under analysis in relation to patents. Meanwhile, the topic of Biochemistry shows relative growth for the year of secrecy, which implies very significant growth for patents associated with this topic of interest.

The correlation of topics of interest for patents and articles, calculated by using the quantities associated with each of the topics (Table I), is positive and high, with a correlation coefficient of 0.782 . Therefore, it is considered possible to establish certain relationships between Scientific Production and
Technological Production, showing horizontal relationships between science and technology for the topics of interest studied here.

Of the 653 articles analyzed (published between 1991 and 2010), 83 (13\%) were published as international collaborations, that is, the authors involved in the co-authorship were from more than one country. The existence of international scientific collaboration in a given area is seen by many researchers (Adams, King \& Singh, 2009; Maricato, 2010; NATIONAL SCIENCE FOUNDATION, 2010) as a sign of maturity, since the tendency is for more recent areas to be studied, initially, by researchers from the same country, and only when a certain degree of maturity is reached is collab-

ISSN: 07I 8-2724. (http://www.jotmi.org) 
oration with other countries undertaken. Analyzing Figure 7 , the growth in collaboration between countries in recent years can be seen.

Figure 7 shows that in 1991 there was no international collaboration (in the sense used here) among articles published.This number increased to $29 \%$ of the total production recorded in 2009 which represented a peak in collaboration between countries. Meanwhile, the pattern of international scientific collaboration in the area assessed shows a lesser volume than the global average. The NATIONAL SCIENCE FOUNDATION (2010) assessed the increase in scientific collaboration between authors from two or more countries. According to this study, the global index (of all scientific areas and fields) of collaboration between countries was $8 \%$ in 1998 , increasing to $22 \%$ in 2007 . When comparing these data with Figure 7, the pattern of international collaboration for articles related to the application of Pochonia Chlamydosporia fungus as a nematicide is less than the global average (3\% in 1998 and $18 \%$ in 2007). On the other hand, the increase in international collaboration in the area seemed to experience increased growth just after 2007, which may indicate a reversal in this difference, possibly due to relatively recent intensification in international scientific collaboration.

\subsection{Market}

The market assessment by the Fund looks to identify the commercial potential of the technology. In accordance with the premises adopted for this study, if there are authors from many countries producing knowledge in one area and the patents are protected in different countries, the market potential is considered to be significant. Therefore, this analysis involves data on scientific production by country, on the countries designated (where the technology is protected) by the patents, and on the scientific and technological topics of interest.

By means of the analysis of scientific production by country of the co-authors, it is possible to choose whether to include the themes of the research agenda of the scientific communities, demonstrating the importance given to the area at national level and how this compares at international level.

Thus, the number of countries considered here as producers of articles related to the application of Pochonia Chlamydosporia fungus as a nematicide, identified in the WoS, for the period 1991 to 2010 , was 55 . The evolution of the quantity of countries with co-authors who published articles related to the subject can be observed from a numbers perspective and is presented in the Figure 8 below.

The non-cumulative indicator reflects the number of countries that published articles in that specific year. The cumulative indicator is the number of countries with co-authors producing scientific articles in the area added to those from the previous year. Negative growth is observed from the non-cumulative perspective, which means that the number of new countries with co-authors publishing articles has diminished. This may be a sign of maturity and/or of a concentration in certain countries, which would seem normal in any area not considered to be new.

Certain countries show continuous production for the period, though many appear for only one or two years. The USA maintains constant production for the entire duration of the period. Meanwhile, Brazil's first publication appears

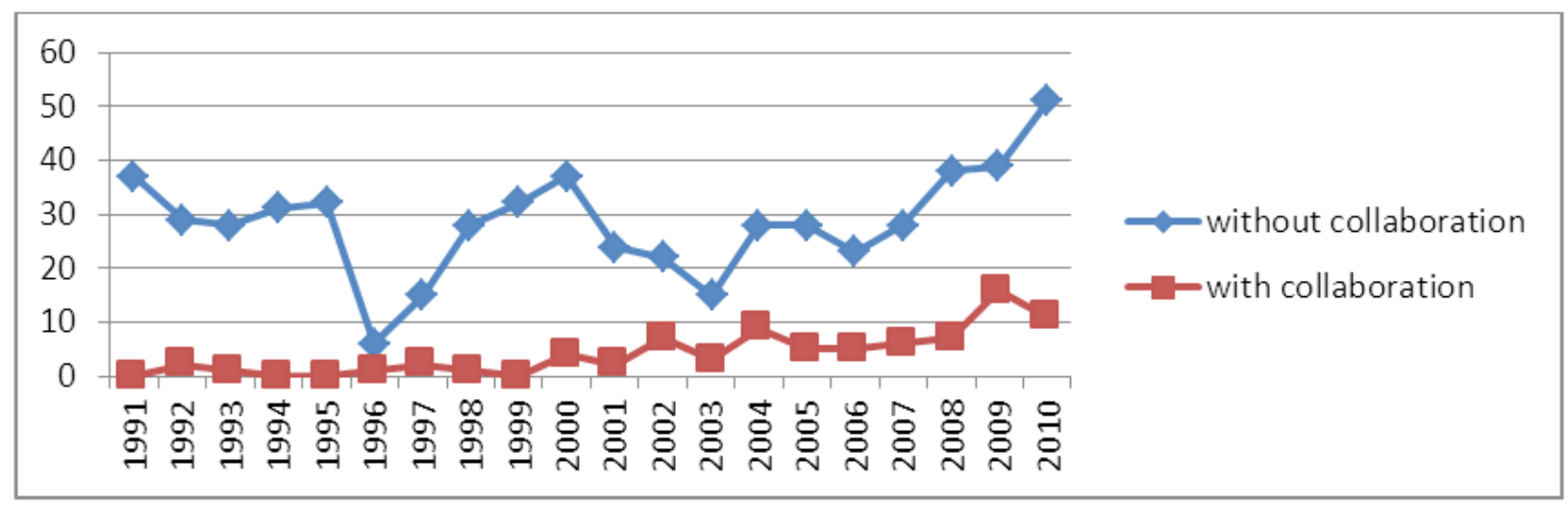

Figure 7. Evolution of the publication of articles related to the application of Pochonia Chlamydosporia fungus as a nematicide with and without international collaboration (1991-2010)

It is important to underline the possible existence of other countries with researchers (or research communities) interested in scientific development in this area, but whose Scientific Production is not indexed in the database used for this analysis.

ISSN: 07 I8-2724. (http://www.jotmi.org)

Journal of Technology Management \& Innovation (C) Universidad Alberto Hurtado, Facultad de Economía y Negocios. 


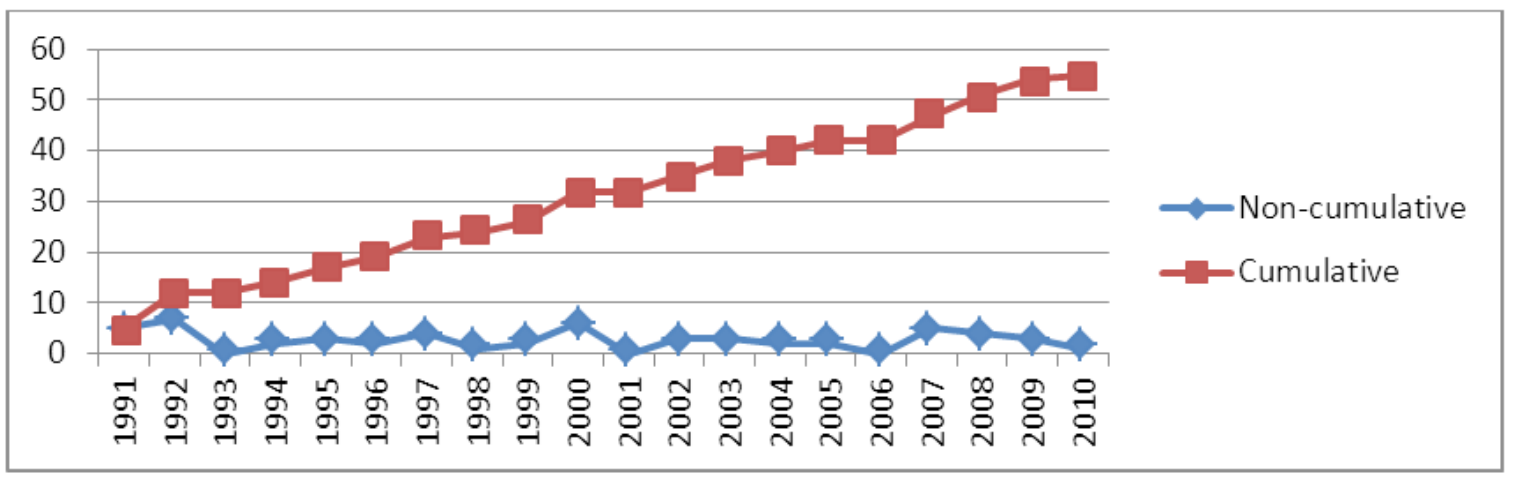

Figure 8. Evolution of the number of countries with co-authors who produced articles related to the application of Pochonia Chlamydosporia fungus as a nematicide - Cumulative and Non-cumulative (1990-2010)

in 2002, although, since then, no other country has shown such an increase in production. In the last four years alone, Brazil went from 2 Ist position (2007) for production by country, in non-cumulative terms, to Ist position in 2010, with average growth of $151 \%$ in the last 3 years, as presented in the Table 2.

In Figure 9, Brazilian scientific production related to the application of Pochonia Chlamydosporia fungus as a nematicide is compared to the three most prolific countries in this area for the period studied here (USA, UK and China). Brazil's progress may be noted, showing a strong tendency toward taking the lead in the area in the coming years.

On the other hand, the number of countries where the patents related to the application of the fungus Pochonia chlamydosporia as nematicide, registered in DIl by the period of 1991 to 2010 at the time of extraction for this study were protected (Designated Countries) is 120 . All of these are shown in Figure 10.

The designated countries are those in which the patent holder declares an interest in protecting the technology developed, and assumes the costs related to its protection. In this way, the designated countries represent the commercial interests of the patent holder. It may be supposed, based on this premise, that the application of Pochonia Chlamydosporia fungus as a nematicide has global commercial potential. It is also possible to list the countries with a greater number of patents of this nature, as is presented in the Table 3 below.

It can be seen that Brazil and China are the only countries of the top four that appear for both production of articles and protection of patents. As mentioned before, the fact that there is a strong preoccupation with patenting among the holders of a given technology in a particular country, im-

\begin{tabular}{|l|l|l|l|l|}
\hline Order & Country & $\begin{array}{l}\text { Number of Ar- } \\
\text { ticles }\end{array}$ & $\begin{array}{l}\text { A v e r a g e } \\
\text { Growth } \\
-2010)\end{array}$ & $\begin{array}{l}\text { A v e r a g e } \\
\text { Growth } \\
(2008 \\
-2010)\end{array}$ \\
\hline 1 & USA & 201 & $47 \%$ & $10 \%$ \\
\hline 2 & UK & 68 & $31 \%$ & $41 \%$ \\
\hline 3 & China & 34 & $61 \%$ & $128 \%$ \\
\hline 4 & Brazil & 31 & $34 \%$ & $151 \%$ \\
\hline 5 & Australia & 27 & $4 \%$ & $0 \%$ \\
\hline 6 & India & 26 & $-10 \%$ & $67 \%$ \\
\hline 7 & Spain & 23 & $-12 \%$ & $50 \%$ \\
\hline 8 & France & 18 & $-48 \%$ & $39 \%$ \\
\hline 9 & Greece & 17 & $5 \%$ & $-56 \%$ \\
\hline 10 & Japan & 16 & $-1 \%$ & $-3 \%$ \\
\hline
\end{tabular}

Table 2. Participation of countries with co-authors in scientific production related to the application of Pochonia Chlamydosporia fungus as a nematicide (199I-2010)

ISSN: 07 I8-2724. (http://www.jotmi.org) 


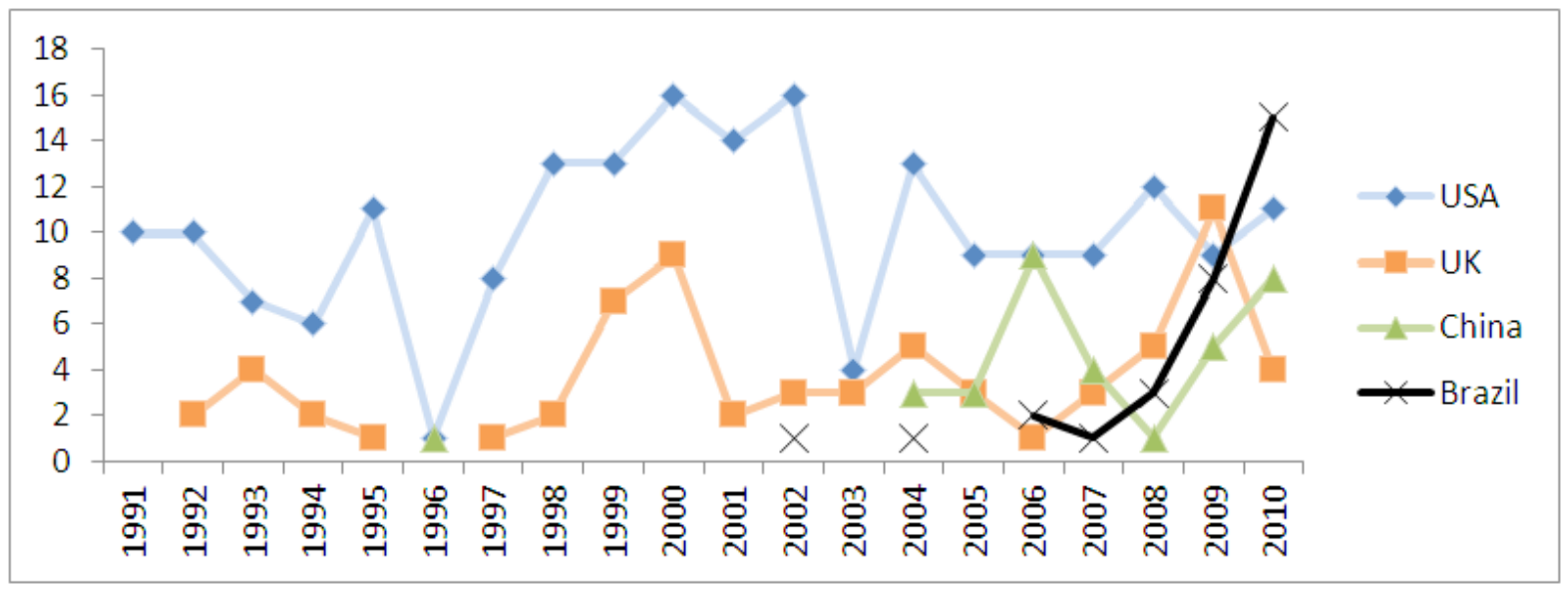

Figure 9. Position of Brazilian scientific production related to the application of Pochonia Chlamydosporia fungus as a nematicide compared to the three most prolific countries in this area - Non-Cumulative (I99I-2010)

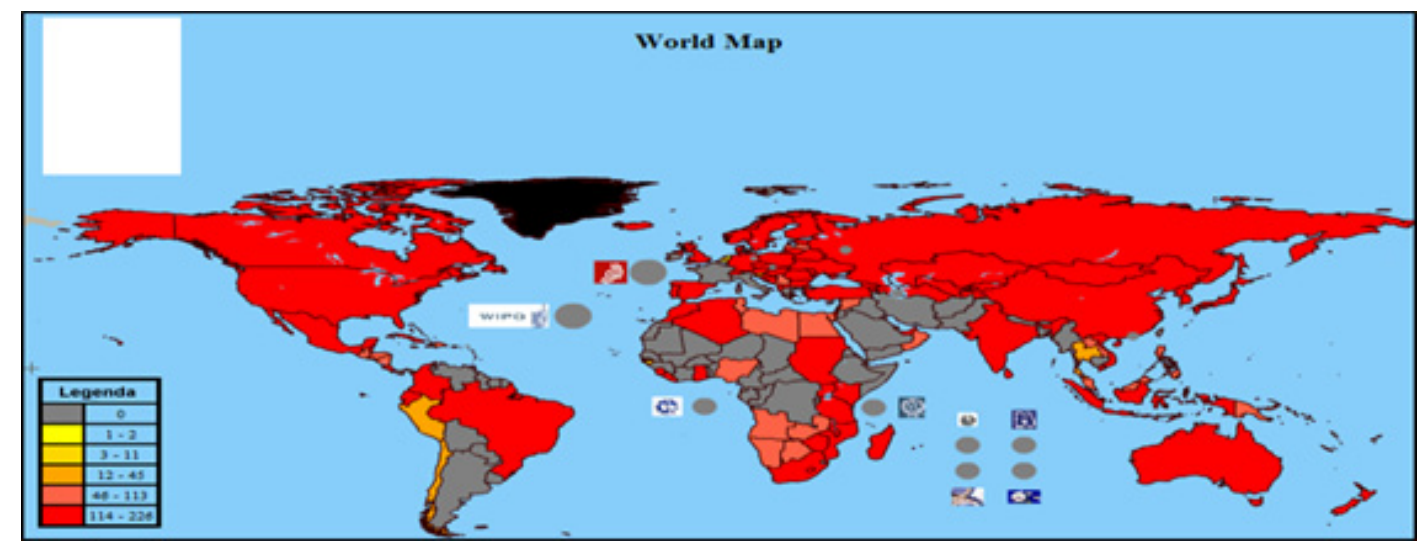

Figure 10. Countries designated by patents related to the application of Pochonia Chlamydosporia fungus as a nematicide (1990-2010)

\begin{tabular}{l|l|l}
\hline Order & Designated Countries & No. of Patents \\
\hline \multirow{2}{*}{1} & Canada & 140 \\
\cline { 2 - 3 } & Japan & 140 \\
\hline \multirow{2}{*}{2} & Australia & 139 \\
\cline { 2 - 3 } & Brazil & 139 \\
\hline \multirow{2}{*}{3} & Norway & 138 \\
\cline { 2 - 3 } & China & 137 \\
\cline { 2 - 3 } & Hungary & 137 \\
\cline { 2 - 3 } & Poland & 137 \\
\cline { 2 - 3 } & Republic of Korea & 137 \\
\cline { 2 - 3 } & Romania & 137 \\
\hline
\end{tabular}

Table 3. Number of patents related to the application of Pochonia Chlamydosporia fungus as a nematicide, by designated country

ISSN: 07 I8-2724. (http://www.jotmi.org)

Journal of Technology Management \& Innovation (C) Universidad Alberto Hurtado, Facultad de Economía y Negocios. 
plies that, according to the premises assumed here, there is a market for the technology in that country. Therefore, even though a technology may be developed in one country and marketed in another, the existence of a domestic market, as is the case in Brazil, associated with leading production of knowledge in the area, is an indicator of the supply and demand capacity of the product.

Figure II allows a global vision, in the form of a network, of the relationships between topics of interest contained in the production of articles and patents by authors from different countries. The red circles in the network represent countries, the black squares represent the topic of interest categories, and the blue squares represent the subject of the patents. The area of the nodes is proportional to the quantity of products (articles and patents) associated and the lines joining them show the relationships between countries and topics of interest according to the type of production.

A much denser network can be seen in the Figure II in relation to topics of interest for patents, since the vast majority of patent holders analysed seek to protect the patents in the same country, independent of the corresponding topic of interest. An even greater concentration can be observed for countries that produce articles as much as they are the subject of technological protection, such as Brazil, as well as those countries (on the left of the graph) that, though not the focus of technological protection, contribute to the generation of knowledge in the area.

\subsection{Divestment}

The main focus of divestment is the withdrawal of seed capital funding from shares in technology based enterprises invested in by the fund. Therefore, this analysis seeks to identify potential organizations that may be interested in the technology studied here. In this way, by assessing the data on productivity, by organization, in articles and patents, the topics of interest and collaboration with other organizations, likely buyers of the technology may be identified.

The number of organizations whose collaborators were authors of articles covered by this study was 406 and the number that registered patents was 254 . Figure 12 shows the

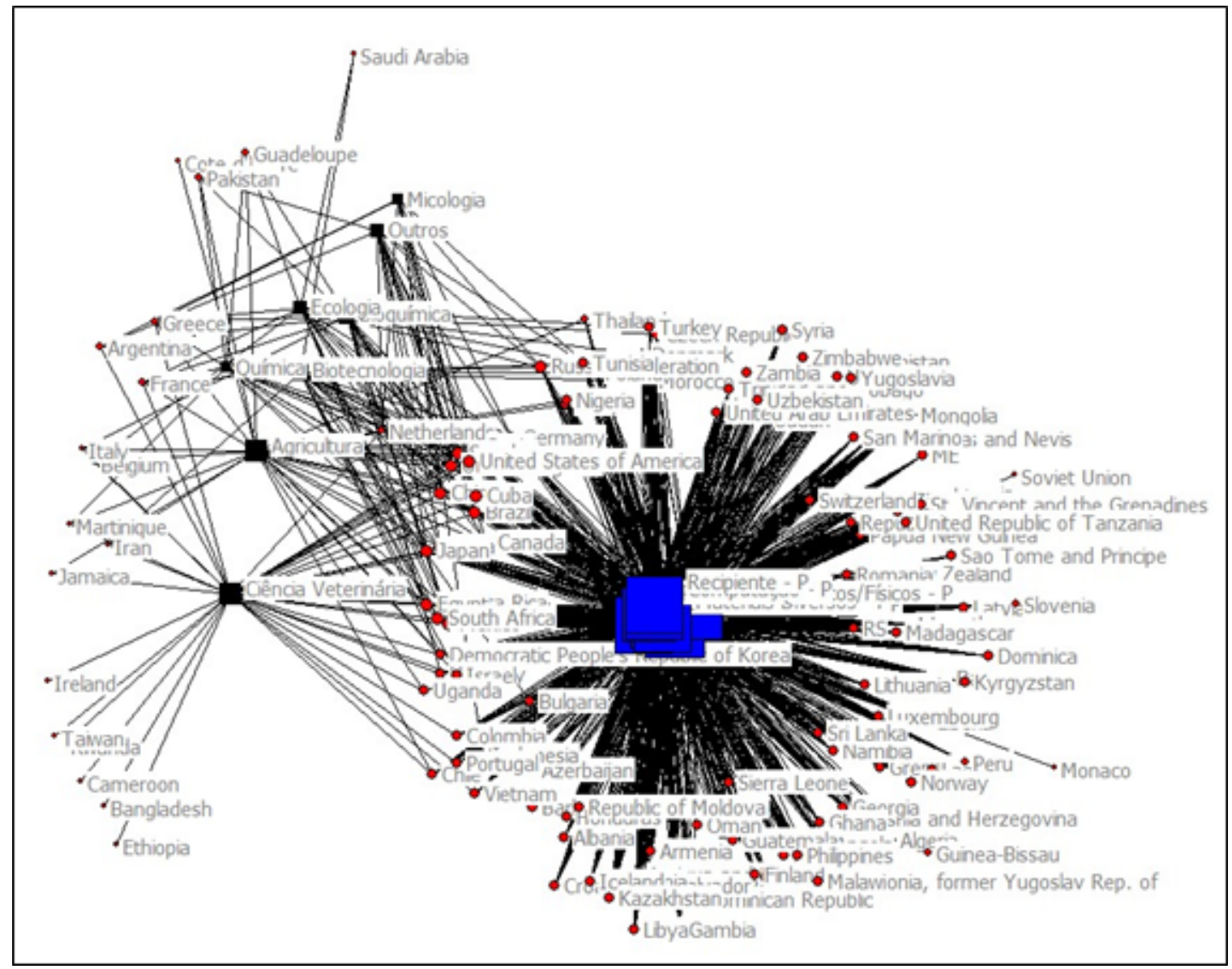

Figure II.Topics of interest of articles and patents related to the application of Pochonia Chlamydosporia fungus as a nematicide, by country and relationships (1990-2010)

ISSN: 07I 8-2724. (http://www.jotmi.org)

Journal of Technology Management \& Innovation (C) Universidad Alberto Hurtado, Facultad de Economía y Negocios. 
evolution of the number of organizations with researchers who published articles related to the technology being assessed. Considering this proxy, the interest of organizations shows average annual growth of $42 \%$ for the period.

In relation to patenting, the interest of organizations also shows greater average annual growth, with an approximate rate of $61 \%$ for the same period, as illustrated in Figure 13. This data shows the increasingly technological focus in the area.

A total of 16 co-active organizations (with as many authors of published articles as patents deposited) were observed and these are listed in Table 4, in descending order, according to the total quantity of documents (patents and articles).

The average number of articles published during the period by authors from co-active organizations, calculated in this way, is approximately 9.3 , while for the organizations which only published articles it is approximately 2 . That is, the coactive organizations are $460 \%$ more productive in the pub- lication of articles than those organizations that only produced articles.

The same is true when comparing the average number of patent registrations by co-active organizations (6.5) with those organizations that only have patents (I.3). In the latter case, the co-active organizations registered $495 \%$ more patents than the organizations which only produced patents. These phenomena will be discussed further in the next section.

Figure 14 below Table 4 shows the network of organizations which registered articles and patents related to the application of Pochonia Chlamydosporia fungus as a nematicide, which are represented as circles.

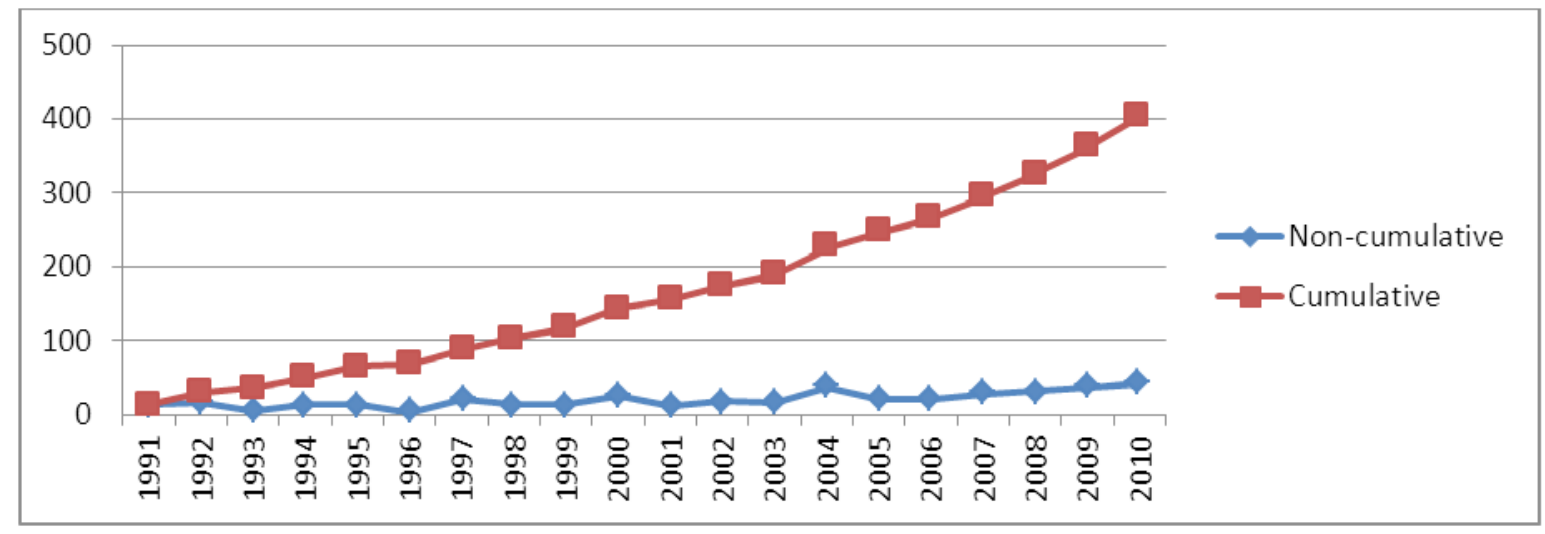

Figure 12. Evolution of organizations that published articles related to the application of Pochonia Chlamydosporia fungus as a nematicide - Cumulative and Non-cumulative (1991-2010)

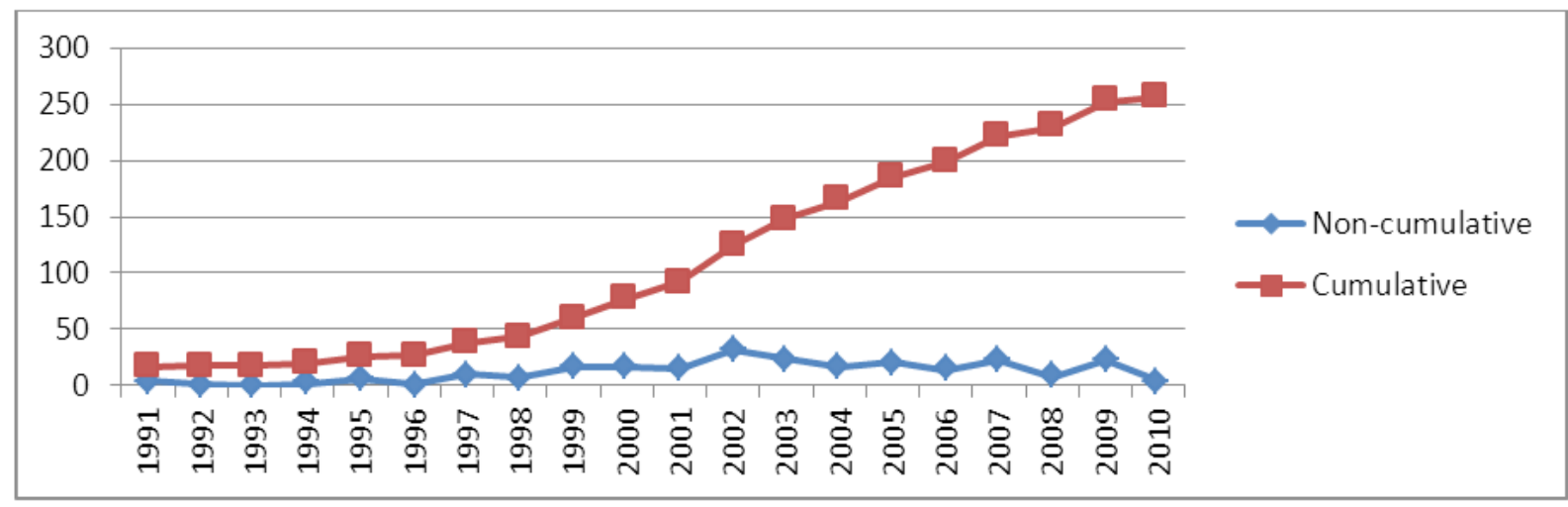

Figure 13. Evolution of organizations that deposited patents related to the application of Pochonia Chlamydosporia fungus as a nematicide - Cumulative and Non-cumulative (I991-2010)

ISSN: 07 I8-2724. (http://www.jotmi.org)

Journal of Technology Management \& Innovation (c) Universidad Alberto Hurtado, Facultad de Economía y Negocios. 


\begin{tabular}{|c|c|c|c|c|}
\hline Organization & Type & Article & $\begin{array}{l}\mathrm{Pa}- \\
\text { tent }\end{array}$ & Total \\
\hline USDA & Go & 44 & 6 & 50 \\
\hline Syngenta & Em & 2 & 38 & 40 \\
\hline Bayer & $\mathrm{Em}$ & 3 & 28 & 31 \\
\hline Univ Florida & Ac & 27 & 1 & 28 \\
\hline Univ California & Ac & 23 & 1 & 24 \\
\hline Auburn Univ & Ac & 11 & 1 & 12 \\
\hline DuPont & Em & 3 & 4 & 7 \\
\hline Ishihara Sangyo Kaisha Ltd & Em & 1 & 5 & 6 \\
\hline Dow & Em & 4 & 1 & 5 \\
\hline Univ Minnesota & Ac & 3 & 2 & 5 \\
\hline Valent Biosci Corp & Em & 4 & 1 & 5 \\
\hline Taisho Pharmaceut Co Ltd & Em & 3 & 1 & 4 \\
\hline Haramaya Univ & Ac & 1 & 1 & 2 \\
\hline Royal Vet \& Agr Univ & Ac & 1 & 1 & 2 \\
\hline
\end{tabular}

Table 4. Co-active organizations (1991-2010)

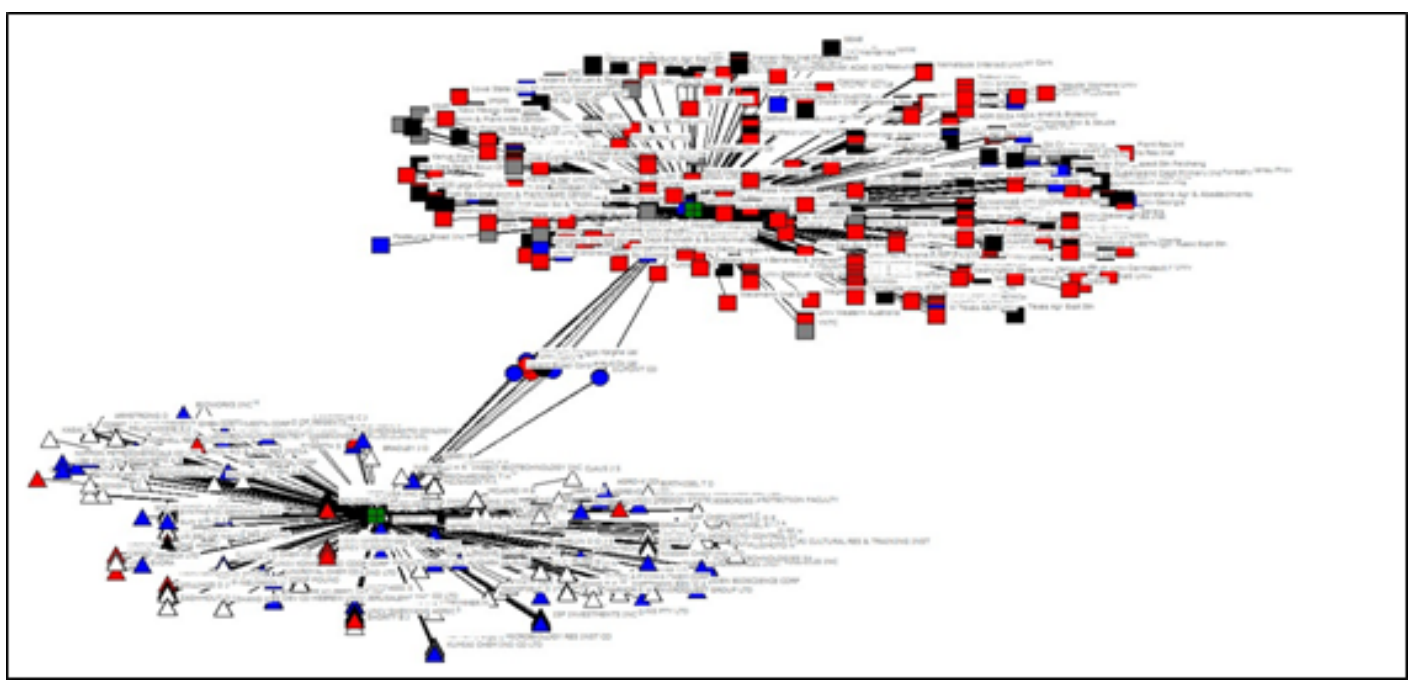

Figure 14. Network of organizations that published/registered articles and patents related to the application of Pochonia Chlamydosporia fungus as a nematicide and their relationships

As may be expected, given the nature of each type of organization, there is a predominance of academic organizations among those that only published articles, and of business organizations among those that only deposited patents.Among the co-active organizations there is more of a balance, with seven business organizations, six academic, as well as just one governmental organization.

With reference to the analysis of topics of interest in scientific production, those denominated Agriculture and Veterinary Science connect with almost all the co-active organizations. Only the Royal University and the Taisho Parmaceut
Co Ltd do not have connections with these subjects, as they are linked exclusively with Biochemistry and Chemistry respectively, as represented in Figure 15.

In order to have a better understanding of the role of coactive organizations in scientific and technological production related to the technology in question, it was sought to verify the characteristics of the network formed between the co-active organizations and those that are not co-active in the production of articles and patents.

ISSN: 07 I8-2724. (http://www.jotmi.org) 


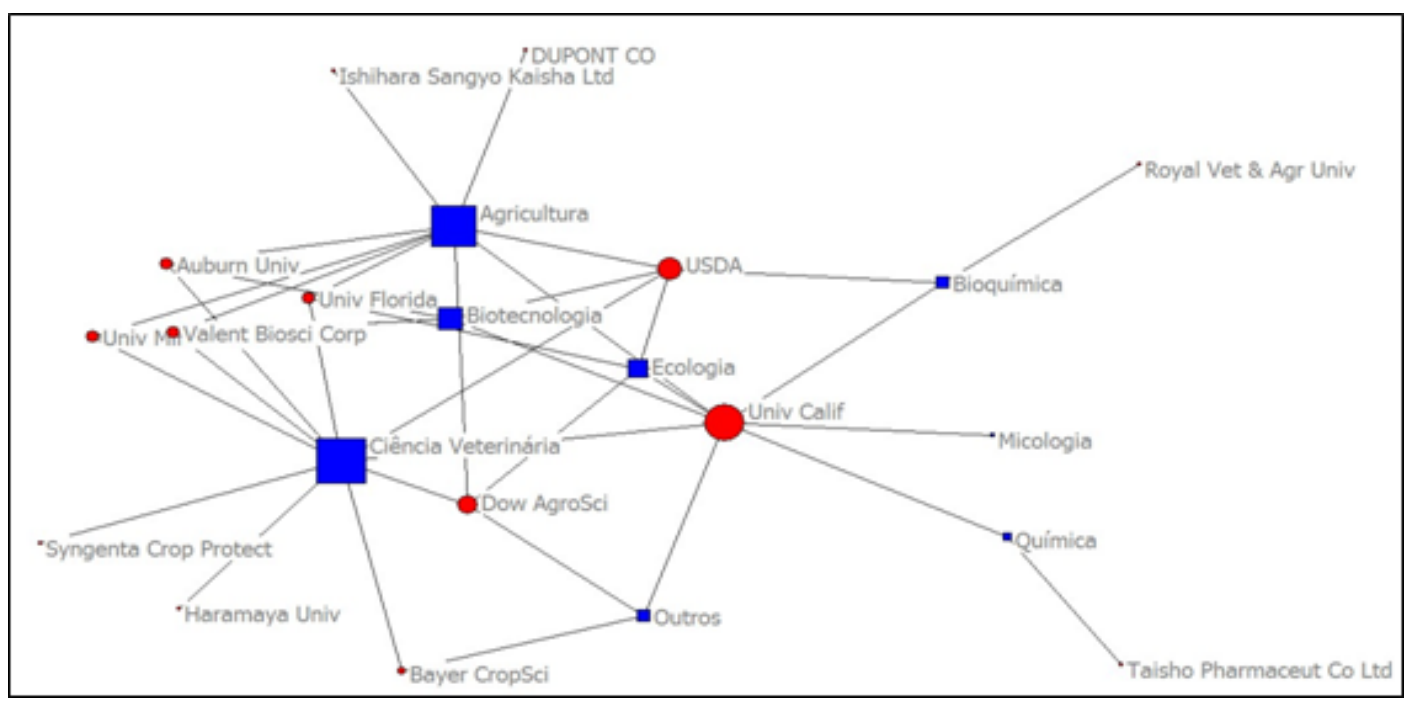

Figure 15. Topics of scientific interest related to the application of Pochonia Chlamydosporia fungus as a nematicide, by co-active organization, and their relationships

Figure 16 shows the network formed by the co-authorships in the publication of articles. It can be seen that the co-active organizations play a central role in the network, connecting with organizations that are not co-active.

Figure 17 shows a network formed by the deposit of patents. A very different view can be seen. In this network, the collaborative activity is much more subdued. The majority of relationships are between two organizations, with the exception of one group, which involves five organizations in which the central one is also the co-active organization, USDA.

\subsection{Team}

Finally, data related specifically to the enterprise analysed was sought, comparing it to more broadly assessed data on technology. Efforts were focused on assessing team production, both in scientific terms (articles) and technological terms (patents), their topics of interest and collaboration with other researchers, organizations and countries.

For the purposes of this analysis, the principal entrepreneur of the enterprise focused on in this study, identified as Freitas, L.G., was considered. As stated in his Curriculum Vitae, this researcher teaches at the Federal University of Viçosa (UFV), where he graduated in Agronomy and studied a Masters in Phytopathology. His doctorate was obtained at the University of Florida. This researcher founded an enterprise in 2008 , where he is both shareholder and scientific coordinator.

In the database analysed, there are two of his articles which can be associated with the enterprise. These articles were co-written with other researchers shown in Figure 18 below, who are associated with UFV, Univiçosa and CNPq (National Council for Scientific and Technological Development), all Brazilian organizations. Thus, international collaborations were not identified in this case. There are also no patents deposited, either under the entrepreneur's name or under the enterprise's name. Neither does he appear as an inventor in any records.

It is worth noting, however, that the UFV is responsible for the majority of Brazilian scientific production in this area, with $58 \%$ of the national production, occupying fifth position among the most prolific organizations in the world.

It is important to observe that the topics of interest of the articles published by the entrepreneur of the enterprise are exclusively associated with Veterinary Science. In an interview, said entrepreneur confirmed that they are studies that deal with results of research on applications of the Pochonia Chlamydosporia fungus. The topic of Veterinary Science was second in global interest in terms of volume of articles and third in terms of patents. In relation to national production, this area contains the greatest volume of records $(39 \%$ of the total).

Among the co-active enterprises, Syngetta and Bayer, the top two enterprises in terms of total volume of scientific and technological production in the area studied, show an interest in Veterinary Science, which, according to the premises of this study, could potentially lead to their selection as possible interested parties in the negotiation of shares in the enterprise when withdrawing funding from its capital structure. 


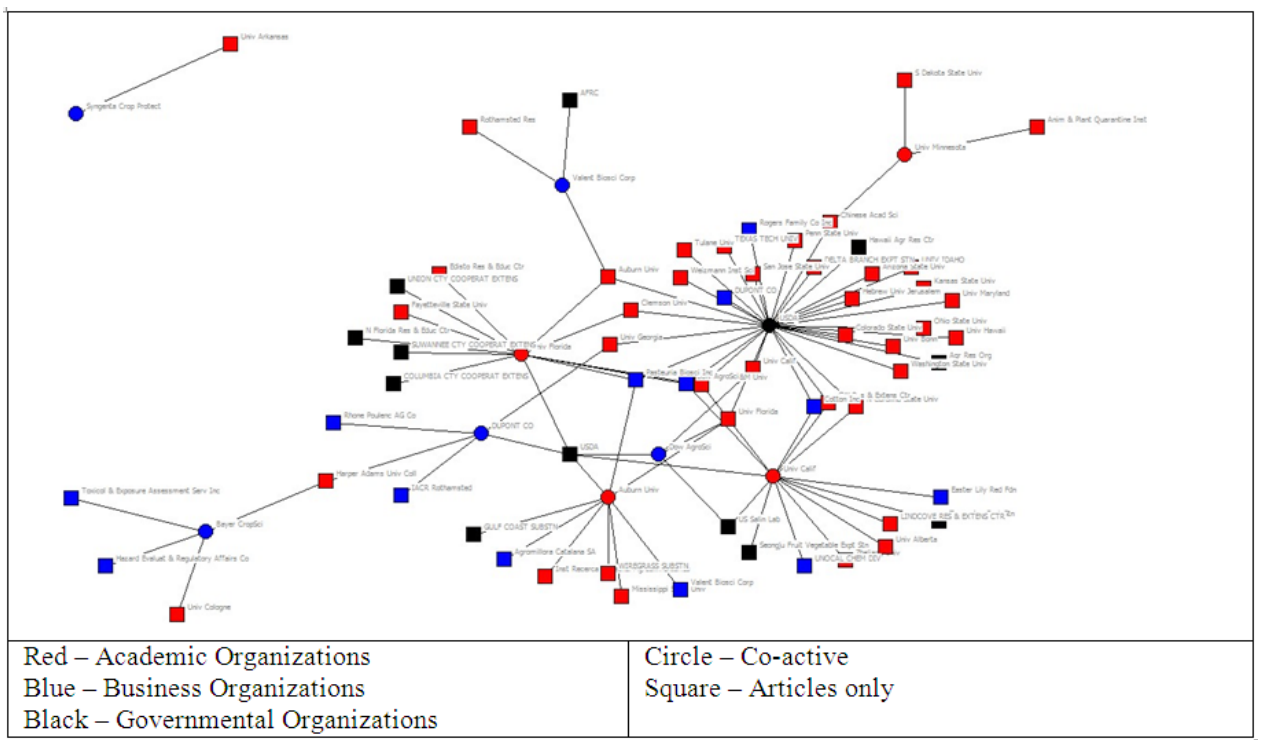

Figure 16. Network of co-active and non co-active organizations in the publication of articles related to the application of Pochonia Chlamydosporia fungus as a nematicide.

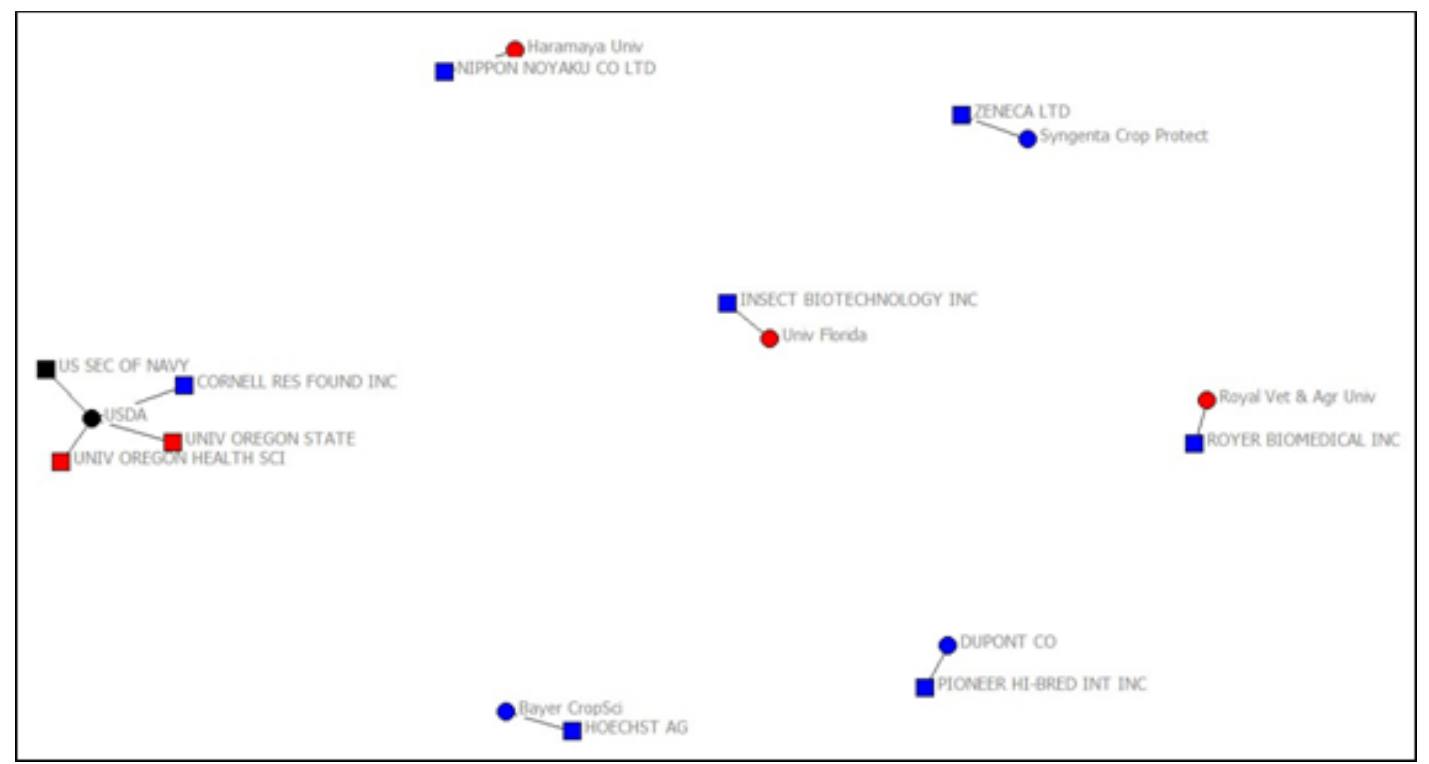

Figure 17. Network of co-active and non co-active organizations in the deposit of patents related to the application of Pochonia Chlamydosporia fungus as a nematicide.

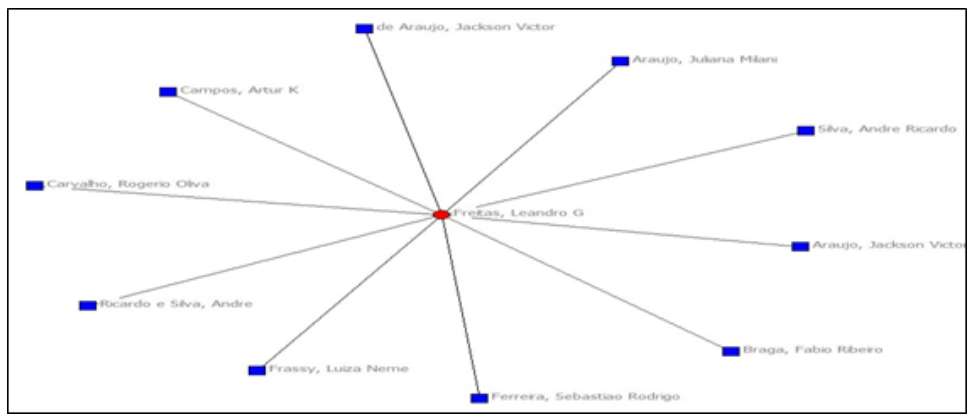

Figure 18. Network of co-authorship of the principal entrepreneur of the enterprise analysed.

ISSN: 07I 8-2724. (http://www.jotmi.org)

Journal of Technology Management \& Innovation (C) Universidad Alberto Hurtado, Facultad de Economía y Negocios. 


\section{Final Considerations}

Based on the data presented, it can be seen that the application of the Pochonia Chlamydosporia fungus as a nematicide has generated an increasing number of patents, with a relationship of 0.346 patents per article, and a tendency to improve this rate (and consequently improve the indicator, in terms of technological focus), as the growth rate for patents is $9 \%$ higher than that for articles, for the period analysed. In terms of Science, the area is also expanding, with the rates above the global average, and with concentrated growth in relation to topics of interest, as well as showing high positive correlation with the subjects covered by the patents. These facts demonstrate the consistency of the scientific basis of the technology assessed. On the other hand, collaborative activity between authors from different countries, for this scientific production, is relatively low. Only 13\% of the production was carried out in collaboration with different countries, which is below the global average. Brazil has a slightly higher rate (16\%), with researchers collaborating in co-authorship with colleagues in Cuba, Spain, France and India.

It may be estimated, based on the proxies adopted here, that there is a very extensive market for this technology, at least geographically. A significant number of countries (55) had researchers publishing articles in this area between 1991 and 2010, with Brazil's notable participation in recent years showing a tendency toward becoming the top country for scientific production, if dynamics in the area remain unchanged. In technological terms, with patents as proxy, the extent is even greater, once the areas of commercial interest, encompassing 120 different countries, are verified. Brazil is again quite central among these countries, showing high commercial interest in the technology being assessed, given its agricultural focus. This characteristic, associated with the high level of scientific production in the field, makes the country very interesting for the development of technology in the area. Initially, this interest comes from the existence of critical mass for the development of the technology, but also from the domestic market for the marketing of related products.

The high level of interest among organizations in the patenting of technologies related to this analysis (whose average annual growth was $61 \%$ ) reaffirms the economic interest in the technology. A high relative rate of business organizations (II\%) with researchers publishing articles in the area can be seen, as well as a predominance of enterprises $(50 \%)$ among the types of co-active organizations. Of these, Syngenta (two articles and 38 patents) and Bayer (three articles and 28 patents) are notable.
Considering the fact that the aim of analysing the technology is to instrumentalize the assessment of a proposal of a given enterprise for investment by a Seed Capital Fund, and that, for this reason, the case of the first enterprise invested in by a specific fund was chosen, a comparative assessment was performed of the general data related to the enterprise's technology, to general production, to the topics of interest, and to collaboration of team members, in this context.

Thus, a more scientific approach of the team may be noted, though with high productivity and adherence to global production despite the apparent lack of international collaboration, based on the data analysed. There are no patents deposited by the enterprise, probably because Pochonia Chlamydosporia is a living thing and national legislation does not consider this type of patenting. Meanwhile, patents related to Measurement and Containers were identified, which could be an alternative for Rizoflora, as a way of protecting its technology and making it more attractive for future negotiations for shares in the fund. In accordance with the analysis performed, the focus on the topic of interest of Veterinary Science makes Syngenta and Bayer potential strategic partners.

\section{Conclusion and limitations}

Based on these analyses, it can be concluded that, in relation to the main objective of this study, the scientometric and patentometric indicators can indeed assist in the assessment of non-financial criteria, particularly in the case of the criteria dealt with in this study, that is: technology, market, divestment and team. Thus, the methodology employed here can be quite useful in instrumentalizing the selection process of projects for seed capital funding, in allowing a better understanding with respect to the dynamics of scientific and technological production related to the product of the enterprises under analysis, and, in a comparative analysis, may facilitate the process of choosing between various projects, through statistical assessment such as the Data Envelopment Analysis, for example.

The main limitation of this study is related to the extraction of data from the WoS and DIl databases. There is an infinity of search strategies which would result in a different range of results. Moreover, the use of the same search strategy for different databases is not necessarily best, since the logic of article publication is different to the logic of patent deposition. Meanwhile, it must be observed that the theme used for this study was validated, by means of an interview, by the entrepreneur. The role of construct indicators and of

Involving packaging for the application of the fungus in various types of crop associated with the occurrence of nematodes or with the reproduction process of the Fungus, for example. 
instruments used for the analysis may produce differences in the interpretation of data. This study, nonetheless, is not proposed as a definitive way of assessing subjective criteria by making it objective via the extraction of data related to articles and patents.

As a contribution to future studies, the use of statistical techniques for the identification of other indicators for the same analysis criteria (technology, market, divestment and team), as well as a comparison of data already gathered, such as information on other enterprises, is suggested.

\section{References}

ACS, Z. J. and Audretsch, D. B. (1987) Innovation, Market Structure, and Firm Size. Review of Economics and Statistics 69(4): 567-74.

ACS, Z. J. and Audretsch, D. B. (1990) Innovation and Small Firms. Cambridge, MA: MIT Press.

ACS, Z. J. and Audretsch, D. B. (I99|) R\&D, Firm Size, and Innovative Activity, in Acs, Z. J. and Audretsch, D. B (eds). Innovation and Technical Change: An International Comparison, Pp. 39-50. New York: Harvester Wheatsheaf.

ADAMS, J; King, C. and Singh, V (2009). Global research report: India: research and collaboration in the new geography of science. Leeds, UK:Thomson Reuters.

ALBUQUERQUE, E. M. (1997) Notas sobre os determinantes tecnológicos do catching up: uma introdução à discussão sobre o papel dos sistemas nacionais de inovação na periferia. Estudos Econômicos, v.27(2).

ALBUQUERQUE, E. M. (1998). Produção científica e sistema nacional de inovação. Ensaios FEE, Porto Alegre, v. I9(I), p. I56-I80.

ALBUQUERQUE, E. M e Sicsú, J. (2000). Inovação institucional e estímulo ao investimento privado. São Paulo em Perspectiva, I4(3), p. I08-II4

ARMOND-DE-MELO, D. R. (20I2). Relação universidadeempresa no Brasil: o papel da academia em redes de coinvenção. Tese de Doutorado, Escola de Administração, UFBA, Salvador, 2012.

AUDRETSCH, D. B. (1995) Innovation and Industry Evolution. Cambridge, MA: MIT Press.

BIRCH, D. L. (1987) Job Creation in America: How Our Smallest Companies put the Most People to Work. New York: Free Press.
BUFREM, L.; Prates, Y (2005). O saber científico registrado e as práticas de mensuração da informação. Ciência da Informação, Brasília, v. 34(2), p. 9-25.

CALLON, M.; Courtial, J y Penan, H (1995). Cienciometría, el estudio cuantitativo de la actividad científica: de la bibliometria a la vigilancia tecnológica. Gijón, TREA.

CAMPOS, A. L. S (2006). Ciência, tecnologia e economia. In: Pelaez, V.; Szmrecsányi, T. (Orgs). Economia da inovação tecnológica. São Paulo: Hucitec.

CARVALHO, A. G., Ribeiro, L. L. e Furtado, C. V. (2006). A indústria de Private Equity e venture capital: primeiro censo brasileiro. São Paulo: Saraiva.

CARVALHO, D. S.; Oliveira, L. G.;Winter, E. \& Mothe, C. G. (2009) Technological Foresight Based on Citing and Cited Patents of Cellulose with Pharmaceutical Applications. Journal of Technology Management \& Innovation 4(4) 32-4I. doi: |0.4067/S07|8-27242009000400003.

CARVALHO, D. S.; Winter, E.; Mothe, C. G. \& Carestiato, T. (20II). Technological Monitoring Applied to Survey-Based on Brazilian Patent Applications about PEMFC. Journal of Technology Management \& Innovation 6(2) 145-160. doi: |0.4067/S07|8-272420II0002000I0.

CGEE (2008) Centro de Gestão e Estudos Estratégicos. Os novos instrumentos de apoio à inovação: uma avaliação inicial. Brasília: ANPEI (Associação Nacional de Pesquisa e Desenvolvimento)

CORTES, H (20I0). Análise da demanda por venture capital no âmbito do FMIEE Criatec. Dissertação (mestrado em Administração). Faculdade Boa Viagem - Recife.

FERREIRA, A. B (2007). O Setor Brasileiro de Capital de Risco: Caracterização, Oportunidades e Perspectivas. 2007. Dissertação (Mestrado em Engenharia da Produção), Universidade Federal Fluminense, Rio de Janeiro.

GARCEZ M.P e Anselmo, J.L (2005). O panorama brasileiro do capital de risco: características, evolução e perspectiva. In: I I ALTEC, 2005, Salvador. Anais eletrônicos do XI Altec. Salvador:ALTEC.

GREGOLIN, J.A. R. et al (2005). Análise da Produção Científica a partir de indicadores bibliométricos. In: Landi, F. R. (Coord.) Indicadores de ciência, tecnologia e inovação em São Paulo 2004. São Paulo: FAPESP, 2005.

GUZMÁN Sánchez, M.V (1999). Patentometría: herramienta para el analisis de oportunidades tecnológicas. 130 p. La 
Habana, 1999. Tesis (Gerencia de información tecnológica)Facultad de Economia. Universidad de La Habana: La Habana.

GVCEPE (2008) Centro de Estudos em Private Equity eVenture Capital da FGV-EAESP. Panorama da Indústria Brasileira de Private Equity e Venture Capital: Relatório de Pesquisa.

HOOD, W.W.; Wilson, C. S (200I). The literature of bibliometrics, scientometrics, and informetrics. Scientometrics, 52 (5).

JANNUZZI, G. M.; Gomes, A. F. e Andrade, H. G (2003). Mapeamento de competências e infraestrutura para P\&D: indicadores para auxílio à prospecção tecnológica na área de energia. Campinas: International Energy Initiative Latin American Office.

MARICATO, J. M (2010). Dinâmica das relações entre Ciência e Tecnologia: estudo Bibliométrico e Cientométrico de múltiplos indicadores de artigos e patentes em biodiesel. Tese (Doutorado) - Universidade de São Paulo, Escola de Comunicação e Artes, Programa de Pós-Graduação em Ciência da Informação, São Paulo.

MACIAS-CHAPULA, C. A (1998). O papel da informetria e da cienciometria e sua perspectiva nacional e internacional. Ciência da Informação, Brasília, v. 27, n. 2, p. 134-140, maio/ ago.

MARTIN,A.R, Faria. L. I. L., Hoffmann,W.A. M. e Gregolin, J.A. R. (2002). Monitoramento de patentes sobre plásticos biodegradáveis. In:WORKSHOP BRASILEIRO DE INTELIGÊN CIA COMPETITIVA E GESTÃO DO CONHECIMENTO, 3., 2002, São Paulo; CONGRESSO ANUAL DA SOCIEDADE BRASILEIRA DE GESTÃO DO CONHECIMENTO, I., 2002, São Paulo.Anais... São Paulo, 2002.

NATIONAL SCIENCE FOUNDATION (20I0). Division of Science Resources Statistics. Science and engineering indicators 2010.Arlington.

OKUBO, Y (1997). Bibliometric indicators and analysis of research systems: methods and examples, OCDE Science, Technology and Industry Working Papers. OCDE Publishing.

OLDHAM, P (2007). Biodiversity and the patent system: towards international indicators. Global Status and Trends in Intellectual Property Claims, United Kingdom, n. 3.

PAVITT, K., Robson, M. and Townsend, J. (1987) 'The Size Distribution of Innovating Firms in the UK: 1945-1983', Journal of Industrial Economics 35(3): 297-316.
PHILLIPS, B. D. and Kirchhoff, B.A. (1989) 'Formation, Growth and Survival: Small Firm Dynamics in the US Economy', Small Business Economics I (I): 65-74.

QUINTELLA, R. H. et al. (2012) Scientific Knowledge Networks in Peripheral Regions and Local Innovation Systems: The Case of Chemistry in the State of Bahia. Journal of Technology Management \& Innovation. 7(I) 85- 103. doi: 10.4067/ S07I8-272420I2000I00006.

REYNOLDS, P. D. (1997) 'New and Small Firms in Expanding Markets', Small Business Economics 9(I): 79-84.

RICKNE, A. and Jacobsson, S. (1999) New Technology-based Firms in Sweden: A Study of their Direct Impact on Industrial Renewal, Economics of Innovation and New Technology 8(3): 197-223.

SCHERER, F. M. (1965) Firm Size, Market Structure, Opportunity, and the Output of Patented Inventions, American Economic Review 55(I): 1097-125.

SCHUMPETER, J. A (1982). Teoria do desenvolvimento econômico. São Paulo,Abril (Os pensadores).

SENGUPTA, I. N (1992). Bibliometrics, informetrics, scientometrics and librametrics: an overview. Libri, v. 42, n. 2, p. 99-135.

SHEARMAN, C. and Burrell, G. (1988) New Technologybased Firms and the Emergence of New Industries, New Technology, Work and Employment 3(2): 87-99.

SOUZA, S (2008). Capital Empreendedor. Curitiba: Juruá.

SPINAK, E (1998). Indicadores cienciométricos. Ciência da Informação, Brasília, v.27, n.2, p. I4I- I48, maio/ago.

STOREY, D. J. and Johnson, S. (1987) Job Generation and Labour Market Change. Basingstoke: Macmillan.

UNESCO (20I0). UNESCO SCIENCE REPORT 20I0. Paris: UNESCO Publishing.

URIONA MALDONADO, M.; Dias, N. e Varvakis, G. (2009). Managing Innovation in Small High-technology Firms:A Case Study in Brazil. Journal of Technology Management \& Innovation. 4(2) I30-I42. doi: I0.4067/S07 I 8-272420090002000 I I.

VELHO, L (1997). Estratégias para um sistema de indicadores de CT\&I no Brasil. In: MINISTÉRIO DA CIÊNCIA E DA TECNOLOGIA. Indicadores de CT\&I no Brasil: antecedentes, estratégia, situação atual, necessidades e perspectivas. Brasília.

ISSN: 07I 8-2724. (http://www.jotmi.org)

Journal of Technology Management \& Innovation (c) Universidad Alberto Hurtado, Facultad de Economía y Negocios. 
J.Technol. Manag. Innov. 2012,Volume 7, Issue 3

ISSN: 07I8-2724. (http://www.jotmi.org)

Journal of Technology Management \& Innovation @ Universidad Alberto Hurtado, Facultad de Economía y Negocios. 